\title{
Female Students' Motor Skills Development by Means of Kangoo Jumps
}

\author{
Grygoriy Griban $^{1, *}$, Mykola Nosko ${ }^{2}$, Yuliia Nosko ${ }^{3}$, Tetiana Zhlobo ${ }^{2}$, Romana Sirenko ${ }^{4}$, \\ Bogdan Semeniv $^{5}$, Zoia Dikhtiarenko ${ }^{6}$, Svitlana Zamrozevuch-Shadrina ${ }^{7}$, Alla Khatko ${ }^{8}$, \\ Ivan Rybchych ${ }^{9}$, Oleksandr Mozolev ${ }^{10}$
}

\begin{abstract}
${ }^{1}$ Department of Physical Education and Sport Improvement, Zhytomyr Ivan Franko State University, Zhytomyr, Ukraine ${ }^{2}$ Department of Pedagogy, Psychology and Methodology of Physical Education, T.H. Shevchenko National University "Chernihiv Colehium", Chernihiv, Ukraine

${ }^{3}$ Department of Preschool and Primary Education, T.H. Shevchenko National University "Chernihiv Colehium", Chernihiv, Ukraine ${ }^{4}$ Department of Physical Training and Sports, Ivan Franko National University of Lviv, Lviv, Ukraine

${ }^{5}$ Department of Physical Education, Sports and Health, Stepan Gzhytskyi National University of Veterinary Medicine and Biotechnologies Lviv, Lviv, Ukraine

${ }^{6}$ Department of Horting and Rehabilitation, University of State Fiscal Service of Ukraine, Irpin, Ukraine

${ }^{7}$ Department of Professional Methods and Technologies of Primary Education, Vasyl Stefanyk Precarpathian National University, Ivano-Frankivsk, Ukraine

${ }^{8}$ Department of Computer Technology in Management and Education and Informatics, Berdyansk State Pedagogical University, Berdyansk, Ukraine

${ }^{9}$ Department of Sport Medicine, Human Health, Ivan BoberskyjLviv State University of Physical Culture, Lviv, Ukraine

${ }^{10}$ Department of Tourism, Theory and Methods of Physical Culture and Valeology, Khmelnytskyi Humanitarian-Pedagogical Academy, Khmelnytskyi, Ukraine
\end{abstract}

Received August 31, 2021; Revised October 9, 2021; Accepted November 5, 2021

\section{Cite This Paper in the following Citation Styles}

(a): [1] Grygoriy Griban, Mykola Nosko, Yuliia Nosko, Tetiana Zhlobo, Romana Sirenko, Bogdan Semeniv, Zoia Dikhtiarenko, Svitlana Zamrozevuch-Shadrina, Alla Khatko, Ivan Rybchych, Oleksandr Mozolev , "Female Students' Motor Skills Development by Means of Kangoo Jumps," International Journal of Human Movement and Sports Sciences, Vol. 9, No. 6, pp. 1324 - 1343, 2021. DOI: 10.13189/saj.2021.090629.

(b): Grygoriy Griban, Mykola Nosko, Yuliia Nosko, Tetiana Zhlobo, Romana Sirenko, Bogdan Semeniv, Zoia Dikhtiarenko, Svitlana Zamrozevuch-Shadrina, Alla Khatko, Ivan Rybchych, Oleksandr Mozolev (2021). Female Students' Motor Skills Development by Means of Kangoo Jumps. International Journal of Human Movement and Sports Sciences, 9(6), 1324 - 1343. DOI: 10.13189/saj.2021.090629.

Copyright $\odot 2021$ by authors, all rights reserved. Authors agree that this article remains permanently open access under the terms of the Creative Commons Attribution License 4.0 International License

\begin{abstract}
The aim of the study is to test the effectiveness of Kangoo Jumps experimentally for the development of female students' motor skills. The main objectives of the study are: to study the interests and motivation of female students for physical education classes, as well as their attitude to Kangoo Jumps classes; to determine the informatively significant indicators of the development of motor skills of female students during Kangoo Jumps classes; and to develop the author's program for the development of female students' motor skills by means of Kangoo Jumps and test its effectiveness. The research was conducted at T. H. Shevchenko National University "Chernihiv Collegium" during 2019-2021. To solve the first objective of our research, we conducted a survey of 1 st and the 2 nd year female students $(\mathrm{n}=286)$
\end{abstract}

according to the questionnaires developed by us; to solve the second objective we investigated the level of development of motor skills of 2nd year female students of the Faculty of Physical Education (Pilot Study Group (PSG), $\mathrm{n}=32$ ), who attended the university section of Kangoo Jumps. The author's program of training sessions with Kangoo Jumps for female students of other faculties of the university was developed based on the research. We organized the pedagogical experiment in order to test the effectiveness of the author's program which involved 1st year female students who were engaged in the author's program during their physical education sessions (experimental group $(\mathrm{EG}), \mathrm{n}=30$ ). Assessment of the development of motor skills was carried out on the following indicators: torso leaning forward from sitting 
position, push-ups, lifting torso to the sitting position over $1 \mathrm{~min}$, Cooper test, running $100 \mathrm{~m}$, shuttle running 4x9 m., stabilographic test of basic exercise on Kangoo Jumps "Fly", tensodynamic test of the basic exercise on Kangoo Jumps - "Jumping Jack". Significant improvement in the level of development of motor skills in the EG female students $(p \leq 0.05)$ was revealed, which testifies to the effectiveness of the author's program for the development of female students' motor skills by means of Kangoo Jumps.

Keywords Female Students, Physical Education, Motor Skills, Kangoo Jumps

\section{Introduction}

Physical education of student youths, in particular girls, requires increased efficiency at the present stage of formation of the national educational system. This is no tonly due to the task of improving the quality of education, but also the general deterioration of health and physical fitness of female students, insufficient humanistic and professional orientation of physical education, reduced motivation for physical exercise, increasing society's requirements for modern specialist training $[1,2,3]$.

Sufficient level of female students' motor skills development, control over the quality of their health, the formation of their need for motor excellence and a healthy lifestyle are prerequisites for successful mastering of future professional activities. The problem of ensuring the optimal development of motor skills and their control is central within the system of physical education $[4,5,6]$. The scientists note that the traditional means, methods, forms and techniques of conducting physical education sessions do not fully solve the problem of purposeful preparation of female students for sports self-education and physical self-improvement $[7,8,9]$.

Recently, modern fitness technologies and innovative methods have been introduced in order to achieve and maintain the optimal physical well-being of a person in accordance with his motivation and individual peculiarities $[10,11,12]$. Kangoo Jumps is one of the types of modern fitness technology that is gaining popularity among students. Kangoo Jumps is a system of various jumping, dancing and playing exercises performed to music. Kangoo Jumps is an original aerobic exercise program, which uses special shoes for elastic jumps, which look like rollers, but without wheels. The basic movements in this program are similar to those performed in traditional aerobics [13]. Kangoo Jumps is an effective means of health training, popular among students and has great potential for health promotion, development of motor skills and creativity of future professionals. KangooJumps sessions evoke positive emotions and a joyful feeling of weightlessness [13]. At this time, insufficient research has been conducted to study the impact of Kangoo Jumps training sessions on the development of motor skills of female students in higher educational institutions.

\subsection{Literature Review}

The works of many scientists $[4,14,15,16]$ state that the students of Ukrainian higher educational institutions health and physical fitness level are unsatisfactory and characterized by the downtrend and the number of students who belong to the physical education group with reduced exercise load and the special medical group is changing from $35 \%$ to $50 \%$ at Ukrainian higher educational institutions. More than $75 \%$ students do not meet the requirements of the physical education program in 2018-2019 [17]. In 2020, the situation worsened due to the pandemic [18]. The scientists [19, 20, 21] consider that a low health and physical fitness level of students is conditioned by a low level of physical development and health of school graduates, the lack of the students' interest and motives of traditional physical education classes; insufficient health-promoting and training orientation of the means of physical education; studying conditions in the modern higher educational institutions that are characterized by increased studying capacity, students' low-level activity and their lifestyle. The majority of the Ukrainian students of both genders (more than $80 \%$ ) have below the middle and low level of health; more than $95 \%$ students are not within the safe zone [22, $23,24]$. It proves the lack of efficiency of the current system of physical education at a Ukrainian higher educational institution and requires new ways of its improvement.

The analysis of the work of many scientists $[3,7,25$, 26,] showed that the introduction of various kinds of modern fitness technologies to the educational process of physical education is one of the most effective ways to increase students' interest in exercise, enhance their physical fitness and strengthen their health. According to the research of the scientists [11,27], it is during training sessions of different types of fitness that a positive emotional background is created, and the level of motor training and interest in physical exercises increases. The scientists note that fitness technologies possess great potential for a healthy lifestyle. Training sessions with different types of fitness technologies effectively influence the correction of the overall appearance, contribute to the harmonization of physical development, and improve the functional state of the body's major systems and mental performance [12, 17, 28].

According to A. E. Carter plyometric exercises are distinguishing characteristics of Kangoo Jumps technology and they have a comprehensive beneficial effect on the human body [29]. He noted that jumping exercises provide an increased gravitational load, which 
strengthens the musculoskeletal system of the body, create a better ratio between the oxygen needed by tissues and oxygen entering the body; promote lymph circulation; reduce the level to which blood pressure rises during exercise; reduce the time during which blood pressure remains abnormally high after exercise; improve the work of the cardiovascular system; contribute to the increase in the number of capillaries in the muscles; make the heart and other muscles of the body stronger, which makes their work more efficient and improve the level of metabolism during rest, so that the body continues to burn calories for a long time after the exercise; increase the activity of nasal bone tissue in the production of red blood cells; improve the brain's response to signals from the vestibular apparatus [29, 30]. Thus, based on the analysis of literature sources, we developed a hypothesis of our research, according to which it is assumed that the introduction of Kangoo Jumps training sessions in the educational process of physical education of female students of higher educational institutions will increase their interest and motivation to exercise and significantly improve development of their motor skills.

\subsection{The Aim}

The aim of the study is to experimentally test the effectiveness of Kangoo Jumps for the development of female students' motor skills.

\subsection{Objectives}

1) To study the interests and motivation of female students for physical education classes, as well as their attitude to Kangoo Jumps classes.

2) To determine the informatively significant indicators of the development of motor skills of female students during Kangoo Jumps classes.

3) To develop the author's program for the development of female students' motor skills by means of Kangoo Jumps and test its effectiveness.

\section{Materials and Methods}

\subsection{Participants}

The research was conducted at T. H. Shevchenko National University "Chernihiv Collegium" (Chernihiv, Ukraine) during 2019-2021.

To solve the first objective of our research, we conducted a survey of 1 st and 2 nd year female students (n =286) according to the questionnaires developed by us; to solve the second objective we investigated the level of development of motor skills of 2nd year female students of the Faculty of Physical Education (Pilot Study Group (PSG), $\mathrm{n}=32$ ), who attended the university section of
Kangoo Jumps. The author's program of training sessions with Kangoo Jumps for female students of other faculties of the university was developed based on the research. We organized the pedagogical experiment in order to test the effectiveness of the author's program which involved 1st year female students who were engaged in the author's program during their physical education sessions (experimental group $(\mathrm{EG}), \mathrm{n}=30$ ). The duration of the experiment is 6 months.

\subsection{Instruments}

The following methods, validity, objectivity and informativeness, which are confirmed by many studies in the field of pedagogy and physical education, were used to solve the tasks: analysis and generalization of literature sources, questionnaires, motor skills testing; computer stabilography, tensodynamography; pedagogical experiment, methods of statistical data processing (Table 1).

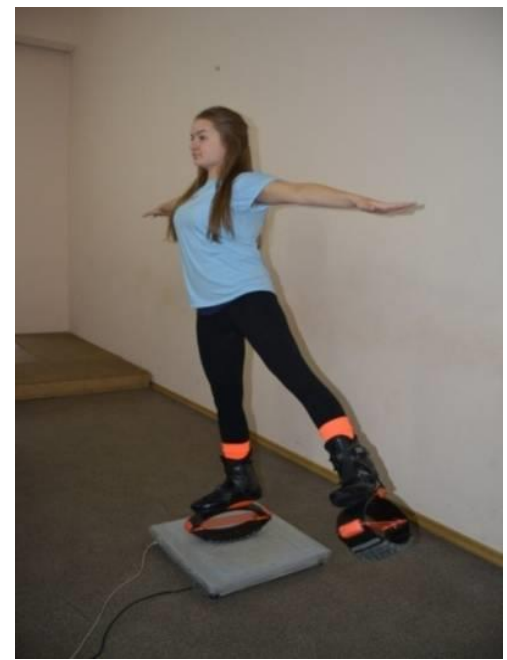

Figure 1. Example of performing the "Fly" muscular endurance test when using the method of computer stabilography

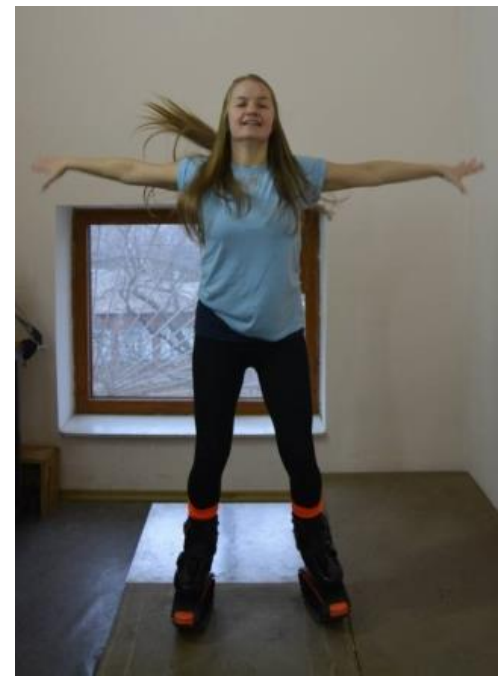

Figure 2. Example of performing the "Jumpimg Jack" muscular endurance test on the strain gauge platform 
Table 1. The content of the methods used in our study

\begin{tabular}{|c|c|}
\hline Methods & The content of the methods \\
\hline $\begin{array}{l}\text { Analysis and } \\
\text { generalization of } \\
\text { literature sources }\end{array}$ & $\begin{array}{l}\text { The analysis and generalization of literature sources were conducted in order to find and systematize the data of } \\
\text { modern pedagogical theory on the peculiarities of age morpho-functional and motor development of female } \\
\text { students, current trends in the content of organization and planning of physical education in higher educational } \\
\text { institutions, determining the importance and features of the development of motor skills of female students of } \\
\text { higher educational institutions. The study of scientific sources (we have processed } 45 \text { sources from the scientific } \\
\text { databases of Scopus, Web of Science and others) made it possible to specify the relevance of the development of } \\
\text { motor skills of female students, identify unresolved and problematic issues, determine scientific tasks for our } \\
\text { own research. }\end{array}$ \\
\hline Questionnaires & $\begin{array}{l}\text { We administered survey of the 1st and the } 2 \text { nd year female students of all specialties of T. H. Shevchenko } \\
\text { National University "Chernihiv Collegium". Two questionnaires were developed for this purpose, which } \\
\text { included } 5 \text { questions, the answers to which allowed determining the motives and needs of female students for } \\
\text { physical education sessions in modern conditions, to obtain information about the interests of female students in } \\
\text { physical exercises, the things that encourage them to engage in motor activities and whether they perform } \\
\text { physical exercises on their own, etc. After all, the motivation of female students is an important component in the } \\
\text { process of organizing physical education sessions, because the motive is a stimulus to a certain activity, action, } \\
\text { deed. It reflects their inner desires and interests in the training sessions, their active and meaningful attitude to } \\
\text { learning. } \\
\text { The questionnaires were assessed by the experts in this field ( } 6 \text { professors and } 9 \text { associate professors) and were } \\
\text { approved by the Academic Council of T. H. Shevchenko National University "Chernihiv Collegium (Protocol } \\
\text { No. } 12 \text { dated } 25.08 .2019) \text {. Consent to voluntary participation in the survey was obtained from all the students } \\
\text { involved in the study. } \\
\text { Author's questionnaires are presented in Appendix } 1 \text {. }\end{array}$ \\
\hline Motor skills testing & $\begin{array}{l}\text { In the study of motor skills of female students, we took into account the fact that it is important to develop all } \\
\text { motor skills for the comprehensive physical development of female students of any specialty, such as: flexibility, } \\
\text { strength, strength endurance, endurance, speed, agility, coordination skills, dynamic strength. The assessment of } \\
\text { the development of female students' motor skills was carried out on the indicators: torso leaning forward from } \\
\text { sitting position (flexibility), push-ups (strength), lifting torso to the sitting position over } 1 \text { min (strength } \\
\text { endurance), Cooper's test (running over } 12 \text { minutes) (endurance), running } 100 \mathrm{~m} \text { (speed), shuttle running } 4 \times 9 \mathrm{~m} \\
\text { (agility), stabilographic test of basic exercise on Kangoo Jumps - "Fly" (static balance performance), } \\
\text { tensodynamic test of basic exercise on Kangoo Jumps - "Jumping Jack" (dynamic strength). The testing of the } \\
\text { level of motor skills development was conducted twice i. e. at the beginning and at the end of the pedagogical } \\
\text { experiment. The content of the tests and the procedure for their implementation are presented in Table } 2 \text {. }\end{array}$ \\
\hline $\begin{array}{c}\text { Computer } \\
\text { stabilography }\end{array}$ & $\begin{array}{l}\text { Computer stabilography was used in order to assess the development of coordination skills. Work on testing the } \\
\text { level of development of coordination skills includes evaluation of the motion control system using a } \\
\text { biomechanical stand on the basis of instrumental techniques i. e. "Stabilan - } 01 \text { " computer stabilizer with } \\
\text { biological feedback, which allows you to quickly analyse the displacement of the total centre of body mass } \\
\text { (TCBM) in frontal and sagittal planes. The object of the research was the analysis of stabilography parameters, } \\
\text { which are associated with displacements of the total centre of body mass of the subjects of interest in static } \\
\text { postures in two mutually perpendicular planes. The stabilogram was registered three times and the indicators for } \\
\text { each female subject of interest were averaged. The stabilographic test included a basic exercise with Kangoo } \\
\text { Jumps - "Fly". Balance is maintained on one leg, while the other one is moved aside with the arms to shoulder } \\
\text { level sideways (Fig. 1). The most informative indicators were identified: - MO (x), mm - average frontal } \\
\text { displacement. - MO (y), mm - average sagittal displacement; - Q (x), mm - frontal scattering. An increase in this } \\
\text { indicator shows a decrease in the stability of the female student in the corresponding plane; - Q (y), mm - sagittal } \\
\text { scattering; - MA - movement assessment. The ratio of the statokinesiogram to the mean scatter, relative to the } \\
\text { duration of the test. Its increase indicates a deterioration in stability, and a decrease indicates an improvement; - } \\
\text { Lx, mm - frontal length of the trajectory of the TCBM; - Ly, mm - sagittal length of the trajectory of the TCBM; } \\
\text { - The quality of the balance function (QBF), \%. The QBF indicator estimates the minimum speed of the TCBM. }\end{array}$ \\
\hline Tensodynamography & $\begin{array}{l}\text { Tensodynamic studies were conducted to research the quantitative indicators of the supporting interactions of the } \\
\text { body of female students during their technical actions. The main biomechanical indicators of support reactions of } \\
\text { female students were realized in the process of using the automated measuring and computing complex: Fz max } \\
\text { - maximum repulsive force relative to the vertical axis; Fx max - maximum repulsive force relative to the } \\
\text { vertical axis; Fy max - maximum repulsive force relative to the frontal axis; F max - maximum value of the } \\
\text { components of the support reactions when performing technical actions (resultant force); F max / P - ratio of the } \\
\text { maximum value of the force indicators of the support reactions to the body weight of the female student; GRAD } \\
\text { - force gradient; I - impulse force; P - weight; H max - maximum height of the female student's total centre } \\
\text { body mass when pushing off the support. The female students undertook the muscular endurance test in the form } \\
\text { of "Jumping Jack" vertical jump from a place (Fig. } 2 \text { ). The registration of indicators of technical actions took } \\
\text { place after the complex of the equipment was preliminary connected to a network ( } 30 \text { min.). The main deviation } \\
\text { of registration of measuring indicators made no more than } \pm 1.0 \% \text { from the maximum value. }\end{array}$ \\
\hline $\begin{array}{c}\text { Pedagogical } \\
\text { experiment }\end{array}$ & $\begin{array}{l}\text { The pedagogical experiment was carried out for the purpose of substantiation, introduction and check of } \\
\text { efficiency of the author's program of female students' motor skills development by means of Kangoo Jumps. The } \\
\text { pedagogical experiment was open. The female students were informed about its aim and tasks, which } \\
\text { significantly increased their motivation to study Kangoo Jumps. }\end{array}$ \\
\hline
\end{tabular}


Table 1. Continued

\begin{tabular}{|c|l|}
\hline & $\begin{array}{l}\text { Methods of statistical data processing were used to process the experimental results of the research in order to } \\
\text { qualitatively and quantitatively analyse them and validate the conclusions. The data of the study were summarized as } \\
\text { numbers, percentages, averages, and standard deviations. To determine the informatively significant indicators of the } \\
\text { development of motor skills of female students during Kangoo Jumps classes we used multiple rank correlation. }\end{array}$ \\
$\begin{array}{c}\text { Methods of } \\
\text { satistical data } \\
\text { processing } \\
\text { standard deviation; } r \text { - correlation coefficient. The significance of the difference between the studied indicators was } \\
\text { assessed by the Student's t-test for related samples at 1\% and 5\% significance levels. All statistical analyses were } \\
\text { performed with the SPSS software, version 21, adapted to medical and biological researches. }\end{array}$ \\
\hline
\end{tabular}

Table 2. The content of female students' motor skills testing

\begin{tabular}{|c|c|c|}
\hline Motor skills & Tests & Testing procedure \\
\hline Flexibility & $\begin{array}{l}\text { Torso leaning } \\
\text { forward from } \\
\text { sitting position } \\
\quad(\mathrm{cm})\end{array}$ & $\begin{array}{l}\text { Preparatory position: sitting on the floor, legs straight in the knees, parallel feet at the width of } 15-20 \\
\mathrm{~cm} \text {, hands on the floor between the knees, palms down. A female student in a sports uniform, which } \\
\text { allows you to determine the straightening of the legs in the knees. She performs two preparatory } \\
\text { elastic leanings by the command "Go!". At the third attempt the female student leans forward as } \\
\text { much as possible, which is delayed with fingers or palms of both hands on a marking line, without } \\
\text { bending legs in the knees, and keeps touch for } 2 \text { seconds. The best value of } 2 \text { attempts was } \\
\text { determined. }\end{array}$ \\
\hline Strength & $\begin{array}{l}\text { Push-ups } \\
\text { (times) }\end{array}$ & $\begin{array}{l}\text { Preparatory position: front support position, arms straightened at shoulder width with hands forward, } \\
\text { torso and legs form a straight line, toes rest on the floor. By the command "Go!" the female student } \\
\text { begins rhythmically bending and unbending her arms with full amplitude. She has to touch the } \\
\text { support with the chest when bending the arms. It is not allowed to touch the support with the thighs, } \\
\text { bend the body and legs, be in the preparatory position and with the arms bent for more than three } \\
\text { seconds, lie on the floor, extend the arms alternately, bend and unbend the arms not with full } \\
\text { amplitude. Bending and unbending the arms performed with errors are not counted. }\end{array}$ \\
\hline $\begin{array}{l}\text { Strength } \\
\text { endurance }\end{array}$ & $\begin{array}{l}\text { Lifting torso to } \\
\text { the sitting } \\
\text { position over } 1 \\
\text { min (times) }\end{array}$ & $\begin{array}{l}\text { Preparatory position: lying on the back on a gymnastic mat, hands behind the head, fingers in the } \\
\text { "lock" position, shoulder-blades touching the mat, legs bent in the knees at right angles, feet pressed } \\
\text { by the partner to the floor. The female student performs the maximum number of torso lifts over } 1 \\
\text { minute, touching the knees with the elbows, followed by returning to the preparatory position. The } \\
\text { number of correctly performed torso lifts is counted. }\end{array}$ \\
\hline Endurance & $\begin{array}{l}\text { Cooper's test } \\
\text { (running over } \\
12 \text { minutes) }(\mathrm{m})\end{array}$ & $\begin{array}{l}\text { The female student begins to move on a flat cinder track of the stadium upon the "Start!" command. } \\
\text { At the end of the time, the distance that the female students managed to cover is measured. }\end{array}$ \\
\hline Speed & $\begin{array}{l}\text { Running } 100 \mathrm{~m} \\
\text { (s) }\end{array}$ & $\begin{array}{l}\text { The female student gets to the starting line upon the "Ready!" command, puts the push leg with the } \\
\text { toe to the line, without crossing it, puts the other leg back, resting the toe on the ground. The opposite } \\
\text { shoulder and arm to the protruding forward leg, are set forward, and the other arm is set back. The } \\
\text { female student bends both legs so that the weight of the body is distributed in the direction in front of } \\
\text { the standing leg upon the "Set!" command. She bends the arms at the elbows and the one opposite to } \\
\text { the put forward leg is set forward. The female student pushes off with the help of the front standing } \\
\text { leg upon the "Go!" command. The swing-up leg is actively brought forward from the thigh, the arms } \\
\text { work crosswise, she runs forward, covers the entire distance and crosses the finish line. The result is } \\
\text { determined by the time of overcoming the distance. }\end{array}$ \\
\hline Agility & $\begin{array}{l}\text { Shuttle running } \\
4 \times 9 \mathrm{~m}(\mathrm{~s})\end{array}$ & $\begin{array}{l}\text { Preparatory position: supporting leg is in front, the push leg is behind. The body is tilted forward, } \\
\text { arms bent at the elbows. The female student runs } 49 \mathrm{~m} \text { long segments upon the "Go!" command. The } \\
\text { result is determined by the time of overcoming the distance. }\end{array}$ \\
\hline $\begin{array}{c}\text { Static } \\
\text { balance } \\
\text { performance }\end{array}$ & $\begin{array}{l}\text { Stabilographic } \\
\text { test of basic } \\
\text { exercise on } \\
\text { Kangoo Jumps } \\
\quad \text {-"Fly" } \\
\end{array}$ & $\begin{array}{l}\text { Preparatory position: standing on one leg, the other set aside at } 45^{\circ} \text {, the torso is straight, and arms are } \\
\text { set to the sides. Balance retention time was recorded. The best value of } 3 \text { attempts was determined. }\end{array}$ \\
\hline $\begin{array}{l}\text { Dynamic } \\
\text { strength }\end{array}$ & $\begin{array}{l}\text { Tensodynamic } \\
\text { test of basic } \\
\text { exercise on } \\
\text { Kangoo Jumps } \\
\text { - "Jumping } \\
\text { Jack" } \\
\end{array}$ & $\begin{array}{l}\text { Preparatory position: narrow stance, knees are slightly bent. Feet are parallel. Back is straight. Centre } \\
\text { of gravity is in the middle. A jump is performed on the inhale pushing off from the platform and } \\
\text { spreading the legs to the sides, slightly wider than the shoulders. Raise your arms to the sides, slightly } \\
\text { bent at the elbows simultaneously with the jump. Land in a wide stance and exhale. The knees remain } \\
\text { slightly bent upon landing. The arms are kept aside. Abdominal muscles are tense, the back is } \\
\text { straight. The jump should be soft and springy. The best value of } 3 \text { attempts is determined. }\end{array}$ \\
\hline
\end{tabular}




\subsection{Procedure}

The research was carried out in four stages.

The scientific and methodological literature of national and foreign authors was analysed and studied during the first stage (September-December 2019), due to which we highlighted the current state, relevance and ways to solve the problem. It also included the definition of the aim of the study, the objectives and the program of the research.

The second stage (January-December 2020) provided for the conduct of the research, which included: survey of female students in order to study their interests and motivation to physical education and to the exercise and their attitude to the introduction of Kangoo Jumps to physical education; the study of the level of development of motor skills of the 2nd year female students of the Faculty of Physical Education in order to determine the informatively significant indicators of the development of motor skills of female students during Kangoo Jumps classes. Based on the conducted research the author's program for the development of motor skills of female students by means of Kangoo Jumps was developed and implemented.

The third stage (February - June 2021) was devoted to the pedagogical experiment in order to test the effectiveness of the proposed program for the development of motor skills of female students by Kangoo Jumps, during which the author's program was introduced into the educational process of female students' physical education.

The fourth stage (July - August 2021) was devoted to the analysis and generalization of the results of the experiment, and the formation of conclusions.

The female students studied Kangoo Jumps twice a week according to the developed author's program of motor skills development. The training sessions lasts 80 minutes.

The initial part (5-10 minutes) of training sessions, which included the organization of students and concentration, focus on emotional and psychological state. The tasks of functional preparation of an organism for the future work in the basic part of the training were solved. This is achieved through special exercises to coordinate movements and music, various steps, walking, general developmental exercises and other exercises that meet the objectives of this part of the training session.

The main part (30-40 minutes) solves the tasks of general and special orientation by means of Kangoo Jumps, develops special and corrective exercises, provides improvement of the technique and style of their performance, practices the coherence of movements with music. The main part of the training session also included acquaintance and practice of set exercises with Kangoo Jumps, performance of a series of dance exercises, application of the exercises aimed at developing motor skills, game exercises, relay races. The main part also provided for cardio-strength training and set exercises aimed at developing flexibility. The structure of the main part changed depending on the recurrence of exercises, their alternation in different starting positions (standing, sitting, in free support, lying), focus (on the development of endurance, strength, speed, agility, coordination, flexibility) and isolated effects on muscles (muscles of the abdomen, back, buttocks, etc.).

The final part lasted 3-5 minutes. It solved the problem of restoring people's strength after exercise. It included the exercises to relax the muscles, both individual parts of the body and the whole body in a standing, sitting, lying posture.

\subsection{Limitation of the Study}

The main limitation of the study is the lack of control of extra-curricular physical activities of the experimental group during the 6 months intervention period.

\subsection{Ethical Approval}

This research complies with the ethical standards of the Act of Ukraine "On Higher Education" No. 1556-VII of July 01, 2014 and the Letter from the Ministry of Education and Science of Ukraine "On the Academic Plagiarism Prevention" No. 1/11-8681 of August 15, 2018. Also, this research followed the regulations of the World Medical Association Declaration of Helsinki - ethical principles for medical research involving human subjects. Informed consent was received from all individuals who took part in this research.

\section{Results}

\subsection{Interests and Motivation of Female Students for Physical Education Classes}

The following data were obtained as a result of processing the answers. $45.10 \%$ of the female students do not like traditional physical education training sessions at the university. As a result, a large percentage of female students miss physical education training sessions: $30.07 \%$ of the female students missed 3-4 training sessions, $19.93 \%$ - 5-10 training sessions, $19.93 \%-1-2$ training sessions. The main reason for skipping training sessions was the lack of desire and interest of female students $(59.79 \%)$. According to $51.05 \%$ of the female students, group training sessions on types of physical activities depending on the interests and desires of female students are the most effective ones. Among the proposed types of physical activities (taking into account the sports facilities and coaches-instructors in the Department of Physical Education of the University), $69.58 \%$ of the female students chose modern fitness technologies (aerobics, Kangoo Jumps, Pilates, stretching, gym, fit-ball aerobics, step aerobics). At the same time, $29.72 \%$ of the female students chose Kangoo Jumps (Table 3). 
Table 3. The results of survey of female students to study their interests and motivation for physical education classes

\begin{tabular}{|c|c|c|c|}
\hline \multirow{2}{*}{ Questions } & \multirow{2}{*}{ Answer options } & \multicolumn{2}{|c|}{ Female students' answers } \\
\hline & & Number & $\%$ \\
\hline \multirow{3}{*}{ Do you exercise on your own? } & yes & 86 & 30.07 \\
\hline & no & 200 & 69.93 \\
\hline & own answer & - & - \\
\hline \multirow{5}{*}{$\begin{array}{c}\text { How many hours a week do you exercise and play } \\
\text { sports? }\end{array}$} & I do not do sports at all & 65 & 22.73 \\
\hline & $1-2$ hours & 106 & 37.06 \\
\hline & 4 hours as it is planned & 72 & 25.17 \\
\hline & $\begin{array}{c}4 \text { hours, as it is planned and additionally during } \\
\text { my personal time }\end{array}$ & 43 & 15.03 \\
\hline & own answer & - & - \\
\hline \multirow{5}{*}{$\begin{array}{l}\text { What is your purpose of doing physical exercises and } \\
\text { sports? }\end{array}$} & increasing physical fitness and health & 100 & 34.97 \\
\hline & improving learning outcomes & 14 & 4.90 \\
\hline & $\begin{array}{l}\text { improving appearance (weight loss), well-being, } \\
\text { mood }\end{array}$ & 86 & 30.07 \\
\hline & $\begin{array}{l}\text { passing the control standards and making the } \\
\text { grade }\end{array}$ & 86 & 30.07 \\
\hline & own answer & - & - \\
\hline \multirow{6}{*}{$\begin{array}{l}\text { How many physical education training sessions did you } \\
\text { miss last semester? }\end{array}$} & none & 57 & 19.93 \\
\hline & $1-2$ & 57 & 19.93 \\
\hline & $3-4$ & 86 & 30.07 \\
\hline & $5-10$ & 57 & 19.93 \\
\hline & 10 and more & 29 & 10.14 \\
\hline & own answer & - & - \\
\hline \multirow{6}{*}{$\begin{array}{c}\text { State the reasons why you miss physical education } \\
\text { training sessions }\end{array}$} & lack of desire and interest & 171 & 59.79 \\
\hline & I do not consider it necessary & - & - \\
\hline & laziness & 29 & 10.14 \\
\hline & disease & 86 & 30.07 \\
\hline & lack of proper conditions & - & - \\
\hline & own answer & - & - \\
\hline \multirow{4}{*}{$\begin{array}{l}\text { How do you think exercise and sports affect the level of } \\
\text { physical fitness and health of female students? }\end{array}$} & positively & 180 & 62.94 \\
\hline & no influence & 106 & 37.06 \\
\hline & negatively & - & - \\
\hline & own answer & - & - \\
\hline \multirow{4}{*}{ Are you satisfied with your level of physical fitness? } & yes & 100 & 34.97 \\
\hline & not completely & 143 & 50.00 \\
\hline & no & 43 & 15.03 \\
\hline & own answer & - & - \\
\hline \multirow{4}{*}{$\begin{array}{l}\text { Do you like traditional physical education training } \\
\text { sessions? }\end{array}$} & yes & 63 & 22.03 \\
\hline & not exactly & 94 & 32.87 \\
\hline & no & 129 & 45.10 \\
\hline & own answer & - & - \\
\hline
\end{tabular}


Table 3. Continued

\begin{tabular}{|c|c|c|c|}
\hline \multirow{4}{*}{$\begin{array}{l}\text { In your opinion, which physical education training } \\
\text { sessions are appropriate? }\end{array}$} & $\begin{array}{c}\text { group training sessions of general physical } \\
\text { training; }\end{array}$ & 71 & 24.83 \\
\hline & $\begin{array}{c}\text { group training sessions of professional and } \\
\text { applied physical training; }\end{array}$ & 69 & 24.13 \\
\hline & $\begin{array}{c}\text { group training sessions on types of physical } \\
\text { activities depending on the interests and desires of } \\
\text { students; }\end{array}$ & 146 & 51.05 \\
\hline & own answer & - & - \\
\hline \multirow{4}{*}{$\begin{array}{l}\text { What types of physical activities would you like to do } \\
\text { during physical education training sessions? }\end{array}$} & $\begin{array}{c}\text { modern fitness technologies (aerobics, Kangoo } \\
\text { Jumps, Pilates, stretching, gym, fit-ball aerobics, } \\
\text { step aerobics) }\end{array}$ & 199 & 69.58 \\
\hline & volleyball & 29 & 10.14 \\
\hline & choreography & 29 & 10.14 \\
\hline & swimming & 29 & 10.14 \\
\hline \multirow{7}{*}{$\begin{array}{l}\text { What types of fitness technologies would you like to do } \\
\text { during physical education training sessions? }\end{array}$} & aerobics & 56 & 19.58 \\
\hline & Kangoo Jumps & 85 & 29.72 \\
\hline & Pilates & 29 & 10.14 \\
\hline & stretching & 29 & 10.14 \\
\hline & gym & 29 & 10.14 \\
\hline & fit ball aerobics & 29 & 10.14 \\
\hline & step aerobics & 29 & 10.14 \\
\hline
\end{tabular}

Table 4. Theresults of correlation analysis of indicators of the female students' motor qualities development $(\mathrm{r}$ critical $=0,349(\mathrm{P}<0.05)$

\begin{tabular}{|c|c|c|c|c|c|c|c|}
\hline Motor skills & Flexibility & Strength & Speed & Endurance & $\begin{array}{c}\text { Strength } \\
\text { endurance }\end{array}$ & Agility & \\
\hline \multicolumn{8}{|l|}{ Flexibility } \\
\hline Strength & -0.148 & & & & & & \\
\hline Speed & 0.891 & 0.317 & & & & & \\
\hline Endurance & -0.961 & -0.132 & -0.982 & & & & \\
\hline Strength endurance & -0.625 & -0.679 & -0.911 & 0.817 & & & \\
\hline Agility & -0.781 & 0.734 & -0.412 & 0.577 & 0.756 & & \\
\hline$\sum r$ & 3.41 & 2.01 & 3.51 & 3.47 & 3.79 & 3.26 & 19.45 \\
\hline$\%$ & 17.53 & 10.33 & 18.05 & 17.84 & 19.49 & 16.76 & 100.00 \\
\hline Rank & 4 & 6 & 2 & 3 & 1 & 5 & \\
\hline
\end{tabular}

\subsection{Informatively Significant Indicators of the Development of Motor Skills of Female Students during Kangoo Jumps Classes}

We determined the informatively significant indicators of the development of motor skills of female students during Kangoo Jumps classes in order to qualitatively build the author's program for the development of motor skills of female students by means of Kangoo Jumps and for a more complete and deeper disclosure of the essence of the phenomenon under analysis. For this purpose, we used the correlation analysis of indicators of various motor skills development of 2 nd year female students of the Faculty of Physical Education (PSG, $\mathrm{n}=32$ ).

Thus, the most informative indicator of female students' motor skills development is the indicator of strength endurance $-19.49 \%$, the second place in terms of informativeness is occupied by the speed indicator -
$18.05 \%$, and the third place is taken by the indicator of endurance $-17.84 \%$, then in terms of informativeness the indicator of flexibility $-17.53 \%$, the indicator of agility $16.76 \%$ and the indicator of strength $-10.33 \%$ (Table 4).

We determined the top eight informative indicators after analysing the results of the basic exercise performance on Kangoo Jumps such as "Jumping Jack" on the strain gauge platform by PSG female students. The first place is occupied by $\mathrm{Fz}$ max indicator (maximum repulsive force relative to the vertical axis) $-14.84 \%$, the second place is taken by $\mathrm{H}$ max indicator (maximum height of the female student's total centre body mass when pushing off the support) $-14.67 \%$, the third place is occupied by $\mathrm{P}$ indicator (weight) $14.64 \%$, the fourth place in terms of informativeness is taken by I indicator (impulse force) - $14.39 \%$, the fifth place - by Fy max (maximum repulsive force relative to the frontal axis) $13.00 \%$, the sixth - by GRAD indicator (force gradient) - 
$11.55 \%$, the seventh - by F max / P indicator (ratio of the maximum value of the force indicators of the support reactions to the body weight of the female student) $9.12 \%$, the eighth - by F max indicator (maximum value of the components of the support reactions when performing technical actions (resultant force)) $-7.78 \%$ (Table 5).

Eight informatively significant biomechanical indicators of coordination qualities of the PSG female students were defined as a result of the analysis of indicators of "Fly" muscular endurance test performance on the force plate. The most significant value is characteristic of $\mathrm{Q}(\mathrm{x})$ indicator (frontal scattering) $15.5 \%$, the second place in terms of significance is MO (x) indicator (average frontal displacement) $-14.31 \%$, the third place is occupied by MO (y) indicator (average sagittal displacement) $-12.74 \%$, the fourth place - QBF indicator (the quality of the balance function) $-12.71 \%$, the fifth place - Lx indicator (frontal length of the trajectory of the TCBM) $-11.51 \%$, the sixth place $-\mathrm{Q}(\mathrm{y})$ indicator (sagittal scattering) - $11.36 \%$, then less significant indicators follow - Ly indicator (sagittal length of the TCBM trajectory) $-11.33 \%$ and MA indicator (movement assessment) is the last, according to the significance $-10.99 \%$ (Table 6). Based on the data obtained we developed the author's program for female students' motor skills development by means of Kangoo Jumps.

Table 5. The results of correlation analysis of indicators the basic exercise performance on Kangoo Jumps such as "Jumping Jack" ( $\mathrm{r}$ critical = 0,349 $(\mathrm{P}<0.05)$

\begin{tabular}{|c|c|c|c|c|c|c|c|c|c|}
\hline Indicators & Fz max & Fx max & Fy max & $\mathbf{P}$ & $F \max / P$ & GRAD & I & $H$ max & \\
\hline \multicolumn{10}{|l|}{ Fz max } \\
\hline Fx max & 0.231 & & & & & & & & \\
\hline Fy max & 0.856 & 0.654 & & & & & & & \\
\hline $\mathrm{P}$ & 0.978 & 0.373 & 0.939 & & & & & & \\
\hline $\mathrm{F} \max / \mathrm{P}$ & 0.583 & -0.433 & 0.101 & 0.399 & & & & & \\
\hline GRAD & 0.723 & -0.455 & 0.261 & 0.571 & 0.943 & & & & \\
\hline I & 0.969 & 0.310 & 0.921 & 0.994 & 0.383 & 0.583 & & & \\
\hline $\mathrm{H} \max$ & 0.983 & 0.330 & 0.924 & 0.999 & 0.424 & 0.602 & 0.997 & & \\
\hline$\sum r$ & 5.32 & 2.79 & 4.66 & 5.25 & 3.27 & 4.14 & 5.16 & 5.26 & 35.85 \\
\hline$\%$ & 14.84 & 7.78 & 13.00 & 14.64 & 9.12 & 11.55 & 14.39 & 14.67 & 100.00 \\
\hline Rank & 1 & 8 & 5 & 3 & 7 & 6 & 4 & 2 & \\
\hline
\end{tabular}

Table 6. The results of correlation analysis of indicators the basic exercise performance on Kangoo Jumps such as "Fly" (r critical = 0,349 ( $\mathrm{P}<0.05)$

\begin{tabular}{|c|c|c|c|c|c|c|c|c|c|}
\hline Indicators & $\operatorname{MO}(\mathbf{x})$ & $\operatorname{MO}(\mathbf{y})$ & $\mathbf{Q}(\mathbf{x})$ & $\mathbf{Q}(\mathbf{y})$ & MA & $\mathbf{L X}$ & $\mathbf{L Y}$ & QBF & \\
\hline \multicolumn{10}{|l|}{ MO (x) } \\
\hline MO (y) & 0.975 & & & & & & & & \\
\hline $\mathrm{Q}(\mathrm{x})$ & 0.956 & 0.866 & & & & & & & \\
\hline $\mathrm{Q}(\mathrm{y})$ & 0.419 & 0.205 & 0.666 & & & & & & \\
\hline MA & -0.294 & -0.073 & -0.561 & -0.991 & & & & & \\
\hline $\mathrm{L}_{\mathrm{X}}$ & 0.895 & 0.972 & 0.725 & -0.030 & 0.163 & & & & \\
\hline $\mathrm{L}_{Y}$ & 0.429 & 0.217 & 0.675 & 0.999 & -0.989 & -0.018 & & & \\
\hline QBF & -0.684 & -0.830 & -0.440 & 0.376 & -0.496 & -0.937 & 0.365 & & \\
\hline$\sum \mathbf{r}$ & 4.65 & 4.14 & 4.89 & 3.69 & 3.57 & 3.74 & 3.68 & 4.13 & 32.49 \\
\hline$\%$ & 14.31 & 12.74 & 15.05 & 11.36 & 10.99 & 11.51 & 11.33 & 12.71 & 100.00 \\
\hline Rank & 2 & 3 & 1 & 6 & 8 & 5 & 7 & 4 & \\
\hline
\end{tabular}




\subsection{Author's Program for the Development of Female Students' Motor Skills by means of Kangoo Jumps}

The construction of the author's program for female students' motor skills development by means of Kangoo Jumps is based on the results of the analysis of long-term research of the scientists on this problem. We also take into account the priorities and interests of female students for modern physical education sessions and forms of their conduct.

Information about the peculiarities of morpho-functional and motor development of student age girls is of particular importance for the construction of the program and the selection of optimal load and exercise.
The mobility of regulatory mechanisms, which is characteristic of the student age, allows building the educational process on the basis of clearly defined patterns of heterochronous development of functional systems.

The availability of information about the peculiarities of female students' state of preparedness, the development of their motor skills is one of the main conditions that ensures the effectiveness and scientific validity of the implementation of the author's program for the development of motor skills by Kangoo Jumps into physical education of female students.

The author's program includes developed set exercises on Kangoo Jumps in the following areas (Table 7).

Table 7. The author's program for the development of female students' motor skills by means of Kangoo Jumps

\begin{tabular}{|c|c|c|}
\hline $\begin{array}{c}\text { Name of the set } \\
\text { exercises / orientation }\end{array}$ & $\begin{array}{c}\text { Exercises that are part of the } \\
\text { set exercises }\end{array}$ & Ways to perform exercises, training methods \\
\hline $\begin{array}{l}\text { «Kangoo Power» } \\
\text { (aimed at developing } \\
\text { endurance and } \\
\text { coordination skills) }\end{array}$ & $\begin{array}{l}\text { Pendulum } \\
\text { Kneelift } \\
\text { Curl } \\
\text { Jog } \\
\text { Jumping Jack } \\
\text { Knee Up } \\
\end{array}$ & $\begin{array}{l}\text { Pendulum - jumping on one leg with a change. } \\
\text { Kneelift- raising the knee of the right and left leg. } \\
\text { Curl - overlapping. Jog - easy running. } \\
\text { Jumping Jack - jumps like legs together legs to the side. } \\
\text { Jump on two legs and land in a wide stance. Knee Up - knee lift. } \\
\text { Training method - interval. }\end{array}$ \\
\hline $\begin{array}{l}\text { «Kangoo Dance» } \\
\text { (aimed at developing } \\
\text { speed, agility and } \\
\text { coordination skills) }\end{array}$ & $\begin{array}{l}\text { Fly } \\
\text { Grapevine } \\
\text { Kicks } \\
\text { Pony } \\
\text { Jump Up } \\
\text { Slalom Ski Jump } \\
\text { Cross Country Ski Jump } \\
\text { V-Step } \\
\text { Mambo Step }\end{array}$ & $\begin{array}{l}\text { Fly - swing straight to the side with a change. } \\
\text { Grapevine step forward, step with the other foot in place, step with the } \\
\text { first foot back, step with the other foot in place. Kicks - blow / swing } \\
\text { from the knee. } \\
\text { Pony - for the first rep you raise the knee forward and up, for the second } \\
\text { rep you lower the leg to the floor and raise the left straight leg to the side. } \\
\text { Jump Up - jumping on two legs. } \\
\text { Cross Country Ski Jump - jumps like right leg forward, left leg back } \\
\text { with a change. V-Step - step with right foot forward to the side, step with } \\
\text { left foot forward to the side, step with right foot back, step with left foot } \\
\text { back. Mambo Step - step forward with the right foot, left foot in place. } \\
\text { Training method - interval. }\end{array}$ \\
\hline $\begin{array}{l}\text { «Kangoo Boot } \\
\text { Camp» } \\
\text { (aimed at developing } \\
\text { strength, strength } \\
\text { endurance) }\end{array}$ & $\begin{array}{l}\text { Set exercises } 1 \\
\text { Wap up. Jog. Down hill. Slalom. } \\
\text { Jumping Jack. } \\
\text { Set exercises } 2 \text { (with dumbbells) } \\
\text { Bending the arms. Lifting in front } \\
\text { of you. Moving aside. Press. } \\
\text { Bent-over rowing. Extension of } \\
\text { the arms at an angle. Extension of } \\
\text { the arms from behind the head. } \\
\text { Set exercises } 2 \text {. } \\
\text { Plank. Squat. Lifting the torso to } \\
\text { the sitting position. Push-ups. }\end{array}$ & $\begin{array}{l}\text { Warp up - warm-up, which should consist of } 1 / 4 \text { the entire distance of } \\
\text { light running. } \\
\text { Jog - running. } \\
\text { Up hill - lifting the knees in turn. } \\
\text { Down hill - alternate overlapping the legs. } \\
\text { Slalom - jumping on two legs. } \\
\text { Training method - circular. }\end{array}$ \\
\hline $\begin{array}{c}\text { «Kangoo Discovery» } \\
\text { (aimed at developing } \\
\text { speed and coordination } \\
\text { skills) }\end{array}$ & $\begin{array}{l}\text { "Accurate" relay race. } \\
\text { "Basketball" relay race. } \\
\text { "Who is faster" Relay race. } \\
\text { "Knocked out" game. }\end{array}$ & $\begin{array}{l}\text { "Accurate" relay race - overcoming the obstacle course from: } \\
\text { coordination ladder, hoops and cones, jumping on one and two legs, you } \\
\text { have to hit the target with a tennis ball. } \\
\text { "Basketball" relay race - passing a basketball in pairs, moving sideways } \\
\text { and throwing the ball into the basketball hoop. } \\
\text { "Who is faster" Relay race - to run in Indian file through the cones and } \\
\text { to return back in Indian file. } \\
\text { "Knocked out" game - dynamic game with fit-ball, two "knockers" are } \\
\text { chosen who try to hit the players with the ball. } \\
\text { The method of training - game and competitive. }\end{array}$ \\
\hline $\begin{array}{c}\text { «Kangoo Stretching» } \\
\text { (aimed at developing } \\
\text { flexibility) }\end{array}$ & $\begin{array}{l}\text { Knees to chest. } \\
\text { Twisting in the lying position. } \\
\text { Rotate the body while sitting. } \\
\text { Leaning to straight legs. } \\
\text { Leaning in the lotus position. } \\
\text { Exercises to stretch the muscles } \\
\text { of chest, arms and shoulder } \\
\text { girdle. }\end{array}$ & $\begin{array}{l}\text { Twisting in the lying position: lying on your back, bend your legs, put } \\
\text { on the floor, put your arms to the sides. Put your feet left and right. } \\
\text { Rotate the body while sitting: cross the right leg over the left. Put the } \\
\text { left elbow on the right knee, pressing it lightly and at the same time } \\
\text { turning the torso to the right. } \\
\text { Leaning to straight legs: put your straight legs to the sides, lean to the } \\
\text { right leg, forward, to the left leg. } \\
\text { Leaning in the lotus position: sit on the floor, feet in the lotus position, } \\
\text { hands behind your head. Lean smoothly to the right to the left, forward. }\end{array}$ \\
\hline
\end{tabular}


Set exercises of "Kangoo Power" consist of basic movements "Jumping Jack", "Kneelift", "Curl", "Pendulum", "Fly", "Jog", which are studied separately and combined into a dance combination with very simple movements and without complicated choreography. "Kangoo Power" set exercises are aimed at developing endurance and coordination, and are performed intensively with the use of interval method. Set exercises of "Kangoo Dance" include basic exercises from the "Kango Power" program and simple dance movements in aerobics. They are combined in a musical progression in the format of 32-64 counts. The exercises are repeated at different levels of intensity and then combined into a choreographic combination. Each new learned movement is added to the previous one. Kangoo "Boot Camp" utilizes strength exercises with and without objects, which are performed by the method of circuit training, without pauses. Training sessions are mostly held outdoors. "Kangoo Discovery" is aimed at developing coordination and speed. Training sessions are held in a fun game form, which includes relay races, games, and competitions. Set exercises of "Kangoo Stretching" used basic stretching exercises performed in Kangoo Jumps shoes. Breathing and relaxation exercises were also used, each training session giving 12 minutes to develop flexibility. The plan of the author's program for the development of female students' motor skills by means of Kangoo Jumps are presented in Appendix 2.

Significant changes in the level of manifestation of motor skills on a number of indicators $(p<0.05)$ were revealed as a result of the special Kangoo Jumps set exercises inclusion in the educational process of physical education of female students in order to develop their motor skills. Thus, the flexibility indicator has improved for $5.4 \mathrm{~cm}$ (changed by $45.49 \%$ ), the strength indicator by 5.64 times $(43.65 \%)$, the speed indicator - by $1.12 \mathrm{~s}$ $(6.64 \%)$, the endurance indicator - by $418.88 \mathrm{~m}$ $(26.71 \%)$, the strength endurance indicator increased by 14.47 times $(42.70 \%)$, the agility indicator - by $1.14 \mathrm{~s}$ $(10.07 \%)$ (Table 8).

The biomechanical characteristics of the dynamics of the manifestation of coordination qualities of female students in the process of "Fly" basic exercise performance were determined using the method of computer stabilography. The following changes have occurred: MO (x) changed by $25.11 \%$, MO (y) - by $25.48 \%$, Q (x) - by $25.93 \%$, Q (y) - by $26.15 \%$, MA by $26.98 \%, \mathrm{~L}_{X}-$ by $26.06 \%, \mathrm{~L}_{\mathrm{Y}}-$ by $26.44 \%, \mathrm{QBF}-$ by $27.52 \%$ (Table 9).

Table 8. Results of motor skills development (Mean \pm SD) before and after the 6-month intervention period of the authors' Kangoo Jump exercise program

\begin{tabular}{|c|c|c|c|c|}
\hline Motor skills & Tests & $\begin{array}{c}\text { Beginning of the } \\
\text { experiment }\end{array}$ & End of the experiment & P (t) \\
\hline Flexibility & $\begin{array}{c}\text { Torso leaning forward from } \\
\text { sitting position (cm) }\end{array}$ & $11.87 \pm 1.26$ & $17.27 \pm 2.32$ & $<0.05(14.730)$ \\
\hline Strength & Push-ups (times) & $12.92 \pm 1.19$ & $18.56 \pm 2.47$ & $<0.05(19.258)$ \\
\hline Speed & Running $100 \mathrm{~m}(\mathrm{~s})$ & $16.86 \pm 2.08$ & $15.74 \pm 1.93$ & $<0.05(2.162)$ \\
\hline Endurance & Running over 12 minutes (m) & $1568.23 \pm 208.45$ & $1987.11 \pm 283.54$ & $<0.05(6.519)$ \\
\hline Strength endurance & $\begin{array}{c}\text { Lifting torso to the sitting } \\
\text { position over 1 min (times) }\end{array}$ & $33.89 \pm 4.58$ & $48.36 \pm 6.92$ & $<0.05(9.551)$ \\
\hline Agility & Shuttle running 4x9 m (s) & $11.32 \pm 1.47$ & $10.18 \pm 1.41$ & $<0.05(3.065)$ \\
\hline
\end{tabular}

Table 9. Stability parameters (Mean \pm SD) of the stabilographic analysis of the "Fly" exercise before and after the 6-month intervention period of the authors' Kangoo Jump exercise program

\begin{tabular}{|c|c|c|c|c|}
\hline $\begin{array}{c}\text { Designation of } \\
\text { characteristics }\end{array}$ & $\begin{array}{c}\text { Unit of } \\
\text { measurement }\end{array}$ & $\begin{array}{c}\text { Beginning of the } \\
\text { experiment }\end{array}$ & End of the experiment & P (t) \\
\hline $\mathrm{MO}(\mathrm{x})$ & $\mathrm{mm}$ & $4.75 \pm 0.48$ & $3.56 \pm 0.37$ & $<0.05(10.755)$ \\
\hline $\mathrm{MO}(\mathrm{y})$ & $\mathrm{mm}$ & $5.73 \pm 0.52$ & $4.27 \pm 0.42$ & $<0.05(11.963)$ \\
\hline $\mathrm{Q}(\mathrm{x})$ & $\mathrm{mm}$ & $4.01 \pm 0.39$ & $2.97 \pm 0.26$ & $<0.05(12.153)$ \\
\hline $\mathrm{Q}(\mathrm{y})$ & $\mathrm{mm}$ & $6.18 \pm 0.61$ & $4.56 \pm 0.48$ & $<0.05(11.431)$ \\
\hline $\mathrm{MA}$ & - & $150.64 \pm 15.34$ & $110.00 \pm 9.76$ & $<0.05(12.243)$ \\
\hline $\mathrm{L}_{\mathrm{X}}$ & $\mathrm{mm}$ & $103.50 \pm 9.86$ & $76.53 \pm 7.19$ & $<0.05(12.105)$ \\
\hline $\mathrm{L}_{\mathrm{Y}}$ & $\mathrm{mm}$ & $154.40 \pm 15.66$ & $113.58 \pm 9.88$ & $<0.05(12.075)$ \\
\hline $\mathrm{QBF}$ & $\%$ & $29.64 \pm 3.27$ & $37.80 \pm 3.59$ & $<0.05(9.204)$ \\
\hline
\end{tabular}


Table 10. Biomechanical parameters (Mean \pm SD) of the analysis of the "Jumping Jack" exercise before and after the 6-month intervention period of the authors' Kangoo Jump exercise program

\begin{tabular}{|c|c|c|c|c|}
\hline $\begin{array}{c}\text { Designation of } \\
\text { characteristics }\end{array}$ & Unit of measurement & $\begin{array}{c}\text { Beginning of the } \\
\text { experiment }\end{array}$ & End of the experiment & P (t.) \\
\hline Fz max & $\mathrm{N}$ & $1676.16 \pm 189.32$ & $2275.24 \pm 226.58$ & $<0.05(11.113)$ \\
\hline Fx max & $\mathrm{N}$ & $75.17 \pm 8.51$ & $97.86 \pm 9.83$ & $<0.05(9.558)$ \\
\hline Fy max & $\mathrm{N}$ & $108.78 \pm 11.16$ & $145.65 \pm 13.26$ & $<0.05(11.652)$ \\
\hline $\mathrm{P}$ & $\mathrm{N}$ & $499.65 \pm 30.83$ & $501.49 \pm 29.69$ & $>0.05(0.235)$ \\
\hline $\mathrm{F} \max / \mathrm{P}$ & $\mathrm{c} \cdot \mathrm{u} \cdot$ & $2.59 \pm 0.28$ & $3.49 \pm 0.31$ & $<0.05(11.801)$ \\
\hline $\mathrm{GRAD}$ & $\mathrm{N} \cdot \mathrm{s}^{-1}$ & $6524.37 \pm 633.45$ & $8875.13 \pm 798.37$ & $<0.05(12.634)$ \\
\hline $\mathrm{I}$ & $\mathrm{N} \cdot \mathrm{s}$ & $81.79 \pm 7.61$ & $110.84 \pm 10.77$ & $<0.05(12.066)$ \\
\hline $\mathrm{H} \max$ & $\mathrm{m}$ & $0.21 \pm 0.03$ & $0.29 \pm 0.04$ & $<0.05(8.764)$ \\
\hline
\end{tabular}

The biomechanical characteristics of the dynamics of the manifestation of female students' strength during the basic movement with Kangoo Jumps of "Jumping Jack" were determined using tensodynametry.

The following changes in the indicators were obtained: Fz max indicator changed by $35.74 \%$, Fx max indicator changed by $30.18 \%$, Fy max indicator changed by $33.89 \%, \mathrm{P}$ indicator changed by $0.37 \%, \mathrm{~F} \max / \mathrm{P}$ indicator changed by $34.75 \%$, GRAD indicator changed by $36.03 \%$, I indicator changed by $35.52 \%$, and $\mathrm{H}$ max indicator changed by $38.10 \%$ (Table 10 ).

The study of the dynamics of motor skills of female students provided objective information about the effectiveness of the program for the development of motor skills of female students using Kangoo Jumps.

A significant increase in motor skills indicators by means of Kangoo Jumps was revealed in the female students after the experiment. This indicates the effectiveness of the implementation of the developed author's program.

\section{Discussion}

Theoretical analysis of scientific and methodological literature [31, 32, 33] gives grounds to assert that the modern system of physical education does not sufficiently meet the needs and motives of female students in motor activities. There is a large percentage of absences from physical education classes due to the decrease in interest and motivation of female students in traditional physical education training sessions. As a result, physical fitness of female students is low. The findings of many scientists were confirmed by the results of our research, where the survey of female students revealed their low level of motivation for traditional physical education training sessions: $45.10 \%$ of the female students do not like traditional physical education training sessions at all, and $32.87 \%$ of the female students said that they do not really like it. Almost $20 \%$ of the female students missed more than a third of physical education training sessions during the semester, indicating a lack of interest in traditional physical education training sessions as the main reason for their absences; more than $30 \%$ of the female students attend physical education training sessions just to make the grade. The number of female students who are partially dissatisfied and completely dissatisfied with their level of physical fitness was over $65 \%$. At the same time, more than $50 \%$ of the female students prefer group training sessions on types of motor activities depending on their interests and desires, where the largest number of female students (almost $70 \%$ ) showed a desire to engage in modern fitness technologies.

Numerous scientific studies have shown that motor activities significantly contribute to a healthy lifestyle, and in some cases reduce the negative impact of bad habits on the human body, but increase stress resistance and distract from antisocial behaviour [17, 34]. According to the World Health Organization, lack of proper motor activities results in economic losses of 150 to 300 Euros per person per year [35].

According to the scientists [12, 14], the level of development of motor skills in the period from 17 to 22 years reaches its maximum in comparison with previous age periods. Student age is the final stage in the development of physiological, mental and functional capabilities of the body, characterized by the final formation of the musculoskeletal system, sensory and motor coordination, autonomic functions of the body, high efficiency. This determines the relevance of the introduction of fitness technologies in the educational process of physical education of female students of higher educational institutions.

The analysis of the state of health activities shows that going in for various types of modern fitness technologies is one of the most popular types of physical education due to their availability, emotionality and efficiency [36]. It is during such training sessions that a positive emotional background is created, the level of motor readiness and interest in physical exercises is increased, skills of organizing a healthy lifestyle are formed [37]. Engagement in the types of modern fitness technologies effectively influence the correction of the general appearance, contribute to the harmonization of motor 
development, and improve the functional status of the basic systems of the body and mental performance [9, 38].

Kangoo Jumps, as a type of modern fitness technology, appeared in 1994. It was the Canadian orthopedist G. Legkhtman who invented unusual spring shoes for the use by his patients as a means of rehabilitating people with back or knee problems. Kangoo Jumps neutralize shock actions on a hard surface, thereby protecting the spine, as well as the knee and ankle joints by $80 \%$. After the presentation of the invention at the exhibition of sporting goods in Paris, the shoes were patented by the Swiss D. Neville [13].

Kangoo Jumps began to be used in physical education from that moment. Scientist, researcher and inventor A. E. Carter was one of the first to study the beneficial effects of jumping exercises on the human body. As a result, A. E. Carter introduced the concept of reboundology (the science of jumping exercises) and conducted many studies over extended periods on the beneficial effects of jumping [29]. The scientist notes that when jumping, people feel that they can work longer, sleep harder; they are less worried and tense. Moreover, the effect is not only psychological, because jumping up and down, which overcomes the force of gravity and does not harm the joints is one of the most effective exercises. According to A. E. Carter, jumping could be done simply on the ground, but the use of a mini-trampoline would be ideal [29]. Trampolines were used so that everyone who was contraindicated in increased loads on the joints could still practice (and jumping on the trampoline just reduced the load on the cardiovascular system and joints). But technology is not standing still, and the trampoline has been replaced by fashionable and bright Kangoo Jumps. According to the scientists, the basic movements in Kangoo Jumps are similar to those performed in traditional aerobics, but are more interesting for female students. [13, 30].

According to the results of our research, it is established that basic motor skills (strength, speed, endurance, coordination: flexibility, agility, balance, ability to orient in space) are developed with the help of Kangoo Jumps training sessions. According to the results of the study on the level of development of motor skills during Kangoo Jumps training sessions for PSG students, we determined the informatively significant indicators of the development of motor skills of female students during Kangoo Jumps classes. Based on conducted researchers we developed the author's program for the development of female students' motor skills by means of Kangoo Jumps and tested its effectiveness. We found that the introduction of Kangoo Jumps fitness programs in the educational process of physical education arouse the female students' interest and motivation for exercise, resulting in their increased motor activities. The results of our research confirm the findings of many scientists [39, $40,41,42,43,44,45]$ and expand them.

\section{Conclusions}

1) The students' interests and motivations for physical education training sessions, as well as their attitude to Kangoo Jumps training sessions were ascertained. It was found that $45.10 \%$ of the female students do not like traditional physical education training sessions at the university; more than $30 \%$ of the female students miss physical education training sessions, indicating a lack of desire and interest $(59.79 \%)$. Among the proposed types of physical activities, $69.58 \%$ of female students chose modern fitness technologies, while $29.72 \%$ of the female students chose Kangoo Jumps. This allowed us to conclude about the need to introduce Kangoo Jumps in the educational process of physical education of female students.

2) The informatively significant indicators of the development of motor skills of female students during Kangoo Jumps classes are determined. Thus, the most informative indicator of the development of motor skills of female students is the indicator of strength endurance $-19.49 \%$, the second most informative one is the indicator of speed $-18.05 \%$, the third place is occupied by the indicator of endurance $-17.84 \%$; the indicator of flexibility $17.53 \%$, the indicator of agility $-16.76 \%$, the indicator of strength $-10.33 \%$. After analysing the results of "Jumping Jack" basic exercise performance with Kangoo Jumps on the strain gauge platform we determined eight most informative indicators of female students: Fz max $-14.84 \%, \mathrm{H}$ $\max -14.67 \%, \mathrm{P}-14.64 \%, \mathrm{I}-14.39 \%$, Fy $\max -$ $13.00 \%$, GRAD - $11.55 \%, \mathrm{~F} \max / \mathrm{P}-9.12 \%$, F $\max -7.78 \%$. Eight informatively significant biomechanical indicators of female students were defined as a result of the analysis of indicators of "Fly" muscular endurance test performance on the force plate: Q (x) - $15.5 \%, \mathrm{MO}(\mathrm{x})-14.31 \%, \mathrm{MO}$ (y) $-12.74 \%, \mathrm{QBF}-12.71 \%, \mathrm{~L} \mathrm{x}-11.51 \%, \mathrm{Q}(\mathrm{y})$ $-11.36 \%$, L y $-11.33 \%$, MA $-10.99 \%$.

3) The author's program, which consisted of Kangoo Jumps set exercises, aimed at developing the female students' motor skills. It was developed and implemented in the educational process of physical education. "Kangoo Power" set exercises were aimed mainly at developing endurance and coordination; "Kangoo Dance" set exercises - for the development of coordination; "Kangoo Boot Camp" set exercises - for the development of strength and endurance; "Kangoo Discovery" - for the development of agility and speed. Significant improvement in the level of development of motor skills in the experimental group female students ( $p \leq$ $0.05)$ was revealed after the pedagogical experiment. This testifies to the effectiveness of the 
implementation of the author's program for the development of female students' motor skills by means of Kangoo Jumps. The results of our research can be used both during physical education training sessions in higher educational institutions and high schools, and during sectional group activities with female students.

Prospects for further research are aimed at studying the level of functional status and health of female students in the process of application of modern fitness technologies, including training sessions with Kangoo Jumps.

\section{Appendix 1}

\section{Disclosure Statement}

No author has any financial interest or received any financial benefit from this research.

\section{Conflict of Interest}

The authors state no conflict of interest.

\begin{abstract}
Author's questionnaires
designed to study the interests and motivation of female students to physical education training sessions, as well as their attitude to Kangoo Jumps training sessions
\end{abstract}

Dear female students!

The Department of Physical Education, T. H. Shevchenko National University "Chernihiv Collegium" appeals to you to answer the questions without missing any of them. The faithfulness of your answers will determine the correctness of our conclusions, which will provide an opportunity to develop practical recommendations for improving the educational process of physical education at our university.

The questionnaire is anonymous, your answers will be used only in a generalized form for scientific purposes only. We hope for your help, sincerely grateful in advance.

\title{
Questionnaire No 1
}

to study the motivation of female students to exercise and sports

1. Do you exercise on your own?

-yes; $\quad$-no;

specify your own answer

2. How many hours a week do you exercise and play sports (given that 4 hours are planned in the educational process of physical education)?

- I do not do sports at all; $\quad-1-2$ hours.; $\quad-4$ hours, as it is planned;

-4 hours, as it is planned and additionally during my personal time;

specify your own answer

3. What purpose do you do physical exercises and sports for?

- increasing physical fitness and health;

- improving learning outcomes;

- improving appearance (weight loss), well-being, mood;

- passing the control standards and making the grade;

specify your own answer

4. How many physical education training sessions did you miss last semester?

-none; $\quad-1-2 ; \quad-3-4 ; \quad-5-10 ; \quad-10$ and more;

specify your own answer

5. State the reasons why you miss physical education training sessions.

- lack of desire and interest; 
- I do not consider it necessary;

- laziness;

- disease;

- lack of proper conditions;

lack of proper conditions

Thank you for participating in the survey!

\section{Questionnaire No 2}

to study the interests and needs of female students for physical education training sessions

1. How do you think exercise and sports affect the level of physical fitness and health of female students?

- positively; - no influence; - negatively;

specify your own answer

\section{Are you satisfied with your level of physical fitness?}

-yes; - not completely; -no;

specify your own answer

3. Do you like traditional physical education training sessions?

-yes; - not exactly; -no;

specify your own answer

4. In your opinion, which physical education training sessions are appropriate?

- group training sessions of general physical training;

- group training sessions of professional and applied physical training;

- group training sessions on types of physical activities depending on the interests and desires of students; specify your own answer

5. What types of physical activities would you like to do during physical education training sessions? (the list of sports is given taking into account the sports base and coaches-instructors in the Department of Physical Education of T. H. Shevchenko National University "Chernihiv Collegium")

- modern fitness technologies (aerobics, Kangoo Jumps, Pilates, stretching, gym, fit-ball aerobics, step aerobics),

- volleyball, - choreography; - swimming.

5a). What types of fitness technologies would you like to do during physical education training sessions?

- aerobics, -Kangoo Jumps, - Pilates, - stretching, -gym, - fit ball aerobics, - step aerobics.

Thank you for participating in the survey! 


\section{Appendix 2}

Action-plan for the development of motor skills of female students by means of Kangoo Jumps

\begin{tabular}{|c|c|c|c|c|}
\hline Cycles & Objectives & Dosing & Means & Notes / Recommendations \\
\hline \multirow{6}{*}{$\begin{array}{l}\text { Cycle I } \\
(1-2 \\
\text { weeks })\end{array}$} & $\begin{array}{c}\text { Assessment of the level of } \\
\text { development of motor skills } \\
\text { of female students and their } \\
\text { functional state }\end{array}$ & $10-15$ minutes & $\begin{array}{l}\text { Standards for physical fitness, } \\
\text { strain gauge, stabilography, } \\
\text { pulsometry }\end{array}$ & $\begin{array}{l}\text { At the beginning of the training } \\
\text { session, at rest, after exercise, at the } \\
\text { end of the session }\end{array}$ \\
\hline & $\begin{array}{c}\text { Preparation for physical } \\
\text { activities }\end{array}$ & 5-10 minutes & $\begin{array}{l}\text { General developmental } \\
\text { exercises }\end{array}$ & Simple exercises \\
\hline & $\begin{array}{l}\text { Learning the basic exercises } \\
\text { of Kangoo Jumps }\end{array}$ & 20-25 minutes & $\begin{array}{l}\text { Basic exercises of Kangoo } \\
\text { Jumps }\end{array}$ & $\begin{array}{l}\text { Emphasis on the technique of } \\
\text { performing basic movements of } \\
\text { Kangoo Jumps }\end{array}$ \\
\hline & Dumbbells technique & $10-15$ minutes & $\begin{array}{c}\text { Power exercises set with } \\
\text { dumbbells }\end{array}$ & $\begin{array}{l}\text { Stationary exercises. Emphasis on } \\
\text { performance technique. }\end{array}$ \\
\hline & $\begin{array}{l}\text { Techniques for performing } \\
\text { exercises to develop } \\
\text { flexibility } \\
\end{array}$ & $10-12$ minutes & $\begin{array}{l}\text { The exercises set aimed at } \\
\text { developing flexibility }\end{array}$ & $\begin{array}{l}\text { Stationary exercises. Emphasis on } \\
\text { performance technique. }\end{array}$ \\
\hline & Recovery after loading & 3-5 minutes & $\begin{array}{l}\text { Exercises to relax the body, } \\
\text { breathing exercises }\end{array}$ & $\begin{array}{l}\text { Simpleexercises to relax the body. } \\
\text { Emphasison relaxation and breathing }\end{array}$ \\
\hline \multirow{5}{*}{$\begin{array}{l}\text { Cycle II } \\
\qquad(3-4 \\
\text { weeks })\end{array}$} & $\begin{array}{c}\text { Preparation for physical } \\
\text { activities }\end{array}$ & 5-10 minutes & $\begin{array}{c}\text { General developmental } \\
\text { exercises }\end{array}$ & Simple exercises \\
\hline & $\begin{array}{l}\text { Learning the basic exercises } \\
\text { of Kangoo Jumps }\end{array}$ & $30-35$ minutes & $\begin{array}{l}\text { Basic exercises of Kangoo } \\
\text { Jumps }\end{array}$ & $\begin{array}{l}\text { Emphasis on the technique of } \\
\text { performing basic movements of } \\
\text { Kangoo Jumps }\end{array}$ \\
\hline & $\begin{array}{c}\text { Technique of performing } \\
\text { strength exercises with one's } \\
\text { own weight } \\
\end{array}$ & 10-18 minutes & $\begin{array}{l}\text { Power exercises set with one's } \\
\text { own weight }\end{array}$ & $\begin{array}{l}\text { Stationary exercises. Emphasis on } \\
\text { performance technique of exercises } \\
\text { with one's own weight. }\end{array}$ \\
\hline & $\begin{array}{c}\text { Introduction to a set of } \\
\text { stretching exercises "For } \\
\text { beginners" }\end{array}$ & 10-12 minutes & $\begin{array}{c}\text { Stretching exercises set «For } \\
\text { beginners» }\end{array}$ & $\begin{array}{c}\text { Simple exercises with emphasis on } \\
\text { stretching muscles, breathing and } \\
\text { pace are performed. }\end{array}$ \\
\hline & Recovery after loading & 3-5 minutes & $\begin{array}{l}\text { Exercises to relax the body, } \\
\text { breathing exercises }\end{array}$ & $\begin{array}{l}\text { Simple exercises to relax the body. } \\
\text { Emphasis on relaxation and breathing }\end{array}$ \\
\hline \multirow{6}{*}{$\begin{array}{l}\text { Cycle III } \\
\qquad(5-6 \\
\text { weeks })\end{array}$} & $\begin{array}{l}\text { Assessment of the level of } \\
\text { development of motor skills } \\
\text { of female students and their } \\
\text { functional state }\end{array}$ & 10-15 minutes & $\begin{array}{l}\text { Standards for physical fitness, } \\
\text { strain gauge, stabilography, } \\
\text { pulsometry }\end{array}$ & $\begin{array}{l}\text { At the beginning of the training } \\
\text { session, at rest, after exercise, at the } \\
\text { end of the session }\end{array}$ \\
\hline & $\begin{array}{c}\text { Preparation for physical } \\
\text { activities }\end{array}$ & 5-10 minutes & $\begin{array}{c}\text { General developmental } \\
\text { exercises }\end{array}$ & Simple exercises \\
\hline & $\begin{array}{c}\text { Learning «Kango Power» } \\
\text { exercises set }\end{array}$ & 20-25 minutes & $\begin{array}{c}\text { Exercises of «Kango Power» } \\
\text { exercises set }\end{array}$ & Emphasis on performance technique. \\
\hline & $\begin{array}{c}\text { Technique of performing } \\
\text { strength exercises with one's } \\
\text { own weight }\end{array}$ & $10-13$ minutes & $\begin{array}{l}\text { Power exercises set with one's } \\
\text { own weight }\end{array}$ & $\begin{array}{l}\text { Stationary exercises. Emphasis on } \\
\text { performance technique of exercises } \\
\text { with one's own weight. }\end{array}$ \\
\hline & $\begin{array}{l}\text { Stretching exercises set «For } \\
\text { beginners» }\end{array}$ & 10-12 minutes & $\begin{array}{l}\text { Stretching exercises «For } \\
\text { beginners» }\end{array}$ & $\begin{array}{l}\text { Simple exercises with emphasis on } \\
\text { stretching muscles, breathing and } \\
\text { pace are performed. }\end{array}$ \\
\hline & Recovery after loading & 3-5 minutes & $\begin{array}{l}\text { Exercises to relax the body, } \\
\text { breathing exercises }\end{array}$ & $\begin{array}{l}\text { Simple exercises to relax the body. } \\
\text { Emphasis on relaxation and breathing }\end{array}$ \\
\hline \multirow{5}{*}{$\begin{array}{l}\text { Cycle IV } \\
\quad(7-8 \\
\text { weeks })\end{array}$} & $\begin{array}{c}\text { Preparation for physical } \\
\text { activities }\end{array}$ & 5-10 minutes & $\begin{array}{c}\text { General developmental } \\
\text { exercises }\end{array}$ & Simple exercises \\
\hline & $\begin{array}{l}\text { Learning «Kango Power» } \\
\text { exercises set }\end{array}$ & 30-40 minutes & $\begin{array}{l}\text { Exercises of «Kango Power» } \\
\text { exercises set }\end{array}$ & $\begin{array}{c}\text { Emphasis on performance technique. } \\
\text { Development of endurance, } \\
\text { coordination } \\
\end{array}$ \\
\hline & $\begin{array}{l}\text { Power exercises set with } \\
\text { one's own weight }\end{array}$ & $10-13$ minutes & $\begin{array}{l}\text { Power exercises set with one's } \\
\text { own weight }\end{array}$ & $\begin{array}{c}\text { Stationary exercises. Performance } \\
\text { technique. }\end{array}$ \\
\hline & Stretching exercises set & 10-12 minutes & Basic stretching exercises & $\begin{array}{c}\text { Exercises with emphasis on } \\
\text { stretching muscles, breathing and } \\
\text { pace. } \\
\end{array}$ \\
\hline & Recovery after loading & 3-5 minutes & $\begin{array}{l}\text { Exercises to relax the body, } \\
\text { breathing exercises }\end{array}$ & $\begin{array}{l}\text { Simple exercises to relax the body. } \\
\text { Emphasis on relaxation and breathing }\end{array}$ \\
\hline
\end{tabular}


Appendix 2 Continued

\begin{tabular}{|c|c|c|c|c|}
\hline \multirow{5}{*}{$\begin{array}{l}\text { Cycle V } \\
(9-10 \\
\text { weeks })\end{array}$} & $\begin{array}{c}\text { Preparation for physical } \\
\text { activities }\end{array}$ & 5-10 minutes & $\begin{array}{c}\text { General developmental } \\
\text { exercises }\end{array}$ & Simple exercises \\
\hline & $\begin{array}{c}\text { Learning «Kangoo Dance» } \\
\text { exercises set }\end{array}$ & 30-40 minutes & $\begin{array}{c}\text { Coordination exercises for arms } \\
\text { and legs }\end{array}$ & $\begin{array}{c}\text { Emphasis on performance technique. } \\
\text { Development of coordination. }\end{array}$ \\
\hline & $\begin{array}{c}\text { Strength set of exercises } \\
\text { with fitballs }\end{array}$ & 10-13 minutes & Strength exercises with fitballs & $\begin{array}{c}\text { Stationary exercises. Performance } \\
\text { technique. }\end{array}$ \\
\hline & $\begin{array}{l}\text { Exercises set to develop } \\
\text { flexibility with gymnastic } \\
\text { balls }\end{array}$ & 10-12 minutes & Exercises with gymnastic balls & $\begin{array}{c}\text { Exercises with emphasis on } \\
\text { stretching muscles, breathing and } \\
\text { pace. }\end{array}$ \\
\hline & Recovery after loading & 3-5 minutes & $\begin{array}{l}\text { Exercises to relax the body, } \\
\text { breathing exercises }\end{array}$ & $\begin{array}{l}\text { Simple exercises to relax the body. } \\
\text { Emphasis on relaxation and breathing }\end{array}$ \\
\hline \multirow{5}{*}{$\begin{array}{l}\text { Cycle VI } \\
(11-12 \\
\text { weeks })\end{array}$} & $\begin{array}{c}\text { Preparation for physical } \\
\text { activities }\end{array}$ & $5-10$ minutes & $\begin{array}{c}\text { General developmental } \\
\text { exercises }\end{array}$ & Simple exercises \\
\hline & $\begin{array}{c}\text { Learning «Kangoo Dance» } \\
\text { exercises set }\end{array}$ & 30-40 minutes & $\begin{array}{l}\text { Complex coordination exercises } \\
\text { for arms and legs }\end{array}$ & $\begin{array}{c}\text { Musical accompaniment 120-124 } \\
\text { beats / minutes } \\
\text { Development of coordination } \\
\text { qualities }\end{array}$ \\
\hline & $\begin{array}{l}\text { Power exercises set with } \\
\text { one's own weight }\end{array}$ & 10-13 minutes & $\begin{array}{l}\text { Power exercises set with one's } \\
\text { own weight }\end{array}$ & $\begin{array}{c}\text { Stationary exercises. Performance } \\
\text { technique. }\end{array}$ \\
\hline & $\begin{array}{l}\text { Yoga exercisesset to } \\
\text { develop flexibility }\end{array}$ & 10-12 minutes & Basic yoga exercises & $\begin{array}{c}\text { Exercises with emphasis on } \\
\text { stretching muscles, breathing and } \\
\text { pace. }\end{array}$ \\
\hline & Recovery after loading & 3-5 minutes & $\begin{array}{l}\text { Exercises to relax the body, } \\
\text { breathing exercises }\end{array}$ & Simple exercises to relax the body. \\
\hline \multirow{5}{*}{$\begin{array}{l}\text { Cycle VII } \\
(13-14 \\
\text { weeks })\end{array}$} & $\begin{array}{c}\text { Preparation for physical } \\
\text { activities }\end{array}$ & 5-10 minutes & $\begin{array}{c}\text { General developmental } \\
\text { exercises }\end{array}$ & Simple exercises \\
\hline & $\begin{array}{c}\text { Learning } \ll \text { Kangoo Boot } \\
\text { Camp» exercises set }\end{array}$ & 30-40 minutes & $\begin{array}{l}\text { Exercises for the development } \\
\text { of strength and endurance }\end{array}$ & $\begin{array}{l}\text { Follow the technique of performing } \\
\text { the exercises }\end{array}$ \\
\hline & $\begin{array}{c}\text { Strengthening the muscles } \\
\text { of the abdomen, back, } \\
\text { buttocks, arms }\end{array}$ & $10-13$ minutes & $\begin{array}{l}\text { Power exercises set in the } \\
\text { ground floor on the mats with } \\
\text { dumbbells }\end{array}$ & $\begin{array}{l}\text { Follow your breathing, exhale with } \\
\text { maximum effort. }\end{array}$ \\
\hline & $\begin{array}{l}\text { Yoga exercises set to } \\
\text { develop flexibility }\end{array}$ & 10-12 minutes & Basic yoga exercises & $\begin{array}{c}\text { Exercises with emphasis on } \\
\text { stretching muscles, breathing and } \\
\text { pace. }\end{array}$ \\
\hline & Recovery after loading & 3-5 minutes & $\begin{array}{l}\text { Exercises to relax the body, } \\
\text { breathing exercises }\end{array}$ & Simple exercises to relax the body. \\
\hline \multirow{5}{*}{$\begin{array}{c}\text { Cycle } \\
\text { VIII } \\
(15-16 \\
\text { weeks })\end{array}$} & $\begin{array}{c}\text { Preparation for physical } \\
\text { activities }\end{array}$ & $5-10$ minutes & $\begin{array}{c}\text { General developmental } \\
\text { exercises }\end{array}$ & Simple exercises \\
\hline & $\begin{array}{l}\text { Learning «Kangoo Boot } \\
\text { Camp» exercises set }\end{array}$ & $30-40 \times \mathbf{x B}$ & $\begin{array}{l}\text { Exercises for the development } \\
\text { of strength and endurance. } \\
\text { Circuit training. } \\
\end{array}$ & $\begin{array}{c}\text { Follow the technique of performing } \\
\text { the exercises. } \\
\text { Exercise in the fresh air. }\end{array}$ \\
\hline & $\begin{array}{c}\text { Strengthening the muscles } \\
\text { of the abdomen, back, } \\
\text { buttocks, arms }\end{array}$ & $10-13 \times$ хв & $\begin{array}{l}\text { Power exercises set in the } \\
\text { ground floor on the mats with } \\
\text { dumbbells }\end{array}$ & $\begin{array}{l}\text { Follow your breathing, exhale with } \\
\text { maximum effort. }\end{array}$ \\
\hline & Pilates exercises set & 10-12 minutes & Basic Pilates exercises & $\begin{array}{c}\text { Exercises with emphasis on } \\
\text { stretching muscles, breathing and } \\
\text { pace. }\end{array}$ \\
\hline & Recovery after loading & 3-5 minutes & $\begin{array}{c}\text { Exercises to relax the body, } \\
\text { breathing exercises }\end{array}$ & Simple exercises to relax the body. \\
\hline \multirow{5}{*}{$\begin{array}{l}\text { Cycle IX } \\
(17-18 \\
\text { weeks })\end{array}$} & $\begin{array}{c}\text { Preparation for physical } \\
\text { activities } \\
\end{array}$ & 5-10 minutes & $\begin{array}{c}\text { General developmental } \\
\text { exercises } \\
\end{array}$ & Simple exercises \\
\hline & $\begin{array}{c}\text { Learning «Kango Power» } \\
\text { exercises set }\end{array}$ & 10-13 minutes & $\begin{array}{c}\text { Basic exercises of «Kango } \\
\text { Power» }\end{array}$ & Follow the performance technique. \\
\hline & «Kangoo Discovery» & 30-40 minutes & Relay and games. & $\begin{array}{c}\text { Emphasis on maintaining balance on } \\
\text { Kangoo Jumps shoes. }\end{array}$ \\
\hline & $\begin{array}{l}\text { Exercises set to develop } \\
\text { flexibility with rubber bands }\end{array}$ & 10-12 minutes & $\begin{array}{l}\text { Exercises to develop flexibility } \\
\text { with rubber bands }\end{array}$ & $\begin{array}{c}\text { Exercises with emphasis on } \\
\text { stretching muscles, breathing and } \\
\text { pace. }\end{array}$ \\
\hline & Recovery after loading & 3-5 minutes & $\begin{array}{l}\text { Exercises to relax the body, } \\
\text { breathing exercises }\end{array}$ & $\begin{array}{l}\text { Simple exercises to relax the body. } \\
\text { Emphasis on relaxation and breathing }\end{array}$ \\
\hline
\end{tabular}


Appendix 2 Continued

\begin{tabular}{|c|c|c|c|c|}
\hline \multirow{5}{*}{$\begin{array}{l}\text { Cycle X } \\
(19-20 \\
\text { weeks })\end{array}$} & $\begin{array}{c}\text { Preparation for physical } \\
\text { activities }\end{array}$ & 5-10 minutes & $\begin{array}{l}\text { General developmental } \\
\text { exercises }\end{array}$ & Simple exercises \\
\hline & «Kangoo Discovery» & $30-40$ minutes & Relay and games & $\begin{array}{l}\text { Emphasis on maintaining balance on } \\
\text { Kangoo Jumps shoes. } \\
\text { Development of speed and agility. }\end{array}$ \\
\hline & $\begin{array}{c}\text { Strengthening the muscles } \\
\text { of the abdomen, back, } \\
\text { buttocks, arms }\end{array}$ & $10-13$ minutes & $\begin{array}{l}\text { Power exercises set in the } \\
\text { ground floor on the mats with } \\
\text { the weight of one's own body }\end{array}$ & $\begin{array}{l}\text { Follow your breathing, exhale with } \\
\text { maximum effort. }\end{array}$ \\
\hline & $\begin{array}{l}\text { Exercises set to develop } \\
\text { flexibility }\end{array}$ & $10-12$ minutes & Exercises to develop flexibility & $\begin{array}{c}\text { Exercises with emphasis on } \\
\text { stretching muscles, breathing and } \\
\text { pace. }\end{array}$ \\
\hline & Recovery after loading & 3-5 minutes & $\begin{array}{l}\text { Exercises to relax the body, } \\
\text { breathing exercises }\end{array}$ & $\begin{array}{l}\text { Simple exercises to relax the body. } \\
\text { Emphasis on relaxation and } \\
\text { breathing }\end{array}$ \\
\hline \multirow{5}{*}{$\begin{array}{l}\text { Cycle XI } \\
(21-22 \\
\text { weeks })\end{array}$} & $\begin{array}{c}\text { Preparation for physical } \\
\text { activities }\end{array}$ & $5-10$ minutes & $\begin{array}{c}\text { General developmental } \\
\text { exercises }\end{array}$ & Simple exercises \\
\hline & $\begin{array}{c}\text { Learning «Kango Power» } \\
\text { exercises set }\end{array}$ & $30-40$ minutes & $\begin{array}{c}\text { Exercises of «Kango Power» } \\
\text { exercises set }\end{array}$ & Emphasis on performance technique. \\
\hline & $\begin{array}{l}\text { Power exercises set with } \\
\text { one's own weight }\end{array}$ & $10-13$ minutes & $\begin{array}{c}\text { Power exercises set with one's } \\
\text { own weight }\end{array}$ & $\begin{array}{c}\text { Stationary exercises. Performance } \\
\text { technique. }\end{array}$ \\
\hline & $\begin{array}{l}\text { Exercises set to develop } \\
\text { flexibility }\end{array}$ & $10-12$ minutes & Exercises to develop flexibility & $\begin{array}{c}\text { Exercises with emphasis on } \\
\text { stretching muscles, breathing and } \\
\text { pace. }\end{array}$ \\
\hline & Recovery after loading & 3-5 minutes & $\begin{array}{l}\text { Exercises to relax the body, } \\
\text { breathing exercises }\end{array}$ & Simple exercises to relax the body. \\
\hline \multirow{5}{*}{$\begin{array}{l}\text { Cycle XII } \\
(23-24 \\
\text { weeks })\end{array}$} & $\begin{array}{c}\text { Preparation for physical } \\
\text { activities }\end{array}$ & $5-10$ minutes & $\begin{array}{c}\text { General developmental } \\
\text { exercises }\end{array}$ & Simple exercises \\
\hline & $\begin{array}{c}\text { Learning «Kangoo Dance» } \\
\text { exercises set }\end{array}$ & $30-40$ minutes & $\begin{array}{c}\text { Exercises of «Kangoo Dance» } \\
\text { exercises set }\end{array}$ & Emphasis on performance technique. \\
\hline & $\begin{array}{l}\text { Power exercises set with } \\
\text { one's own weight }\end{array}$ & $10-13$ minutes & $\begin{array}{c}\text { Power exercises set with one's } \\
\text { own weight }\end{array}$ & $\begin{array}{c}\text { Stationary exercises. Performance } \\
\text { technique. }\end{array}$ \\
\hline & $\begin{array}{l}\text { Exercises set to develop } \\
\text { flexibility }\end{array}$ & 10-12 minutes & Exercises to develop flexibility & $\begin{array}{c}\text { Exercises with emphasis on } \\
\text { stretching muscles, breathing and } \\
\text { pace. }\end{array}$ \\
\hline & Recovery after loading & 3-5 minutes & $\begin{array}{l}\text { Exercises to relax the body, } \\
\text { breathing exercises }\end{array}$ & $\begin{array}{l}\text { Simple exercises to relax the body. } \\
\text { Emphasis on relaxation and } \\
\text { breathing }\end{array}$ \\
\hline
\end{tabular}

\section{REFERENCES}

[1] K. Prontenko, I. Bloshchynskyi, G. Griban, Ye. Zhukovskyi, T. Yavorska, P. Tkachenko, D. Dzenzeliuk, N. Dovgan, S. Bezpaliy, V. Andreychuk. "Formation of readiness of future physical culture teachers for professional activity", Universal Journal of Educational Research. Vol.7, No.9, pp. 1860-1868, 2019. doi: 10.13189/ujer.2019.070903

[2] G. Griban, T. Yavorska, P. Tkachenko, O. Kuvaldina, Z. Dikhtiarenko, E. Yeromenko, A. Lytvynenko, N. Hresa, I. Okhrimenko, I. Ovcharuk, K. Prontenko. "Motor activity as the basis of a healthy lifestyle of student youth", Wiadomości Lekarskie, Vol.73, No.6, pp. 1199-1206, 2020. doi: 10.36740/WLek202006123

[3] O. Mozolev, I. Bloshchynskyi, K. Prontenko, L. Zdanevych, K. Kruty, O. Popovych, L. Pisotska. "Influence of fitness techniques integration on the development of physical qualities and morpho-functional state of adult females", Human Movement, Vol.22, No.1, pp. 57-65, 2021; doi: https://doi.org/10.5114/hm.2021.984
65

[4] K. Prontenko, G. Griban, N. Dovgan, O. Loiko, V. Andreychuk, P. Tkachenko, D. Dzenzeliuk, I. Bloshchynskyi "Students' health and its interrelation with physical fitness level", Sport Mont, Vol. 17, No.3, pp. 41-46, 2019. doi 10.26773/smj.191018

[5] O. Tymoshenko, V. Arefiev, Zh. Domina, T. Malechko, T. Bondar, M. Tymchyk, O. Pliushchakova, V. Riabchenko, G. Griban, K. Prontenko. "Exercise machines in speed and coordination development among students playing basketball". International Journal of Human Movement and Sports Sciences, Vol.9, No.2, pp. 347-355, 2021. doi: 10.13189/saj.2021.090224

[6] G. Griban, O. Kuznietsova, P. Tkachenko, D. Oleniev, O. Khurtenko, Z. Dikhtiarenko, E. Yeromenko, A. Lytvynenko, A. Khatko, L. Pustoliakova, "Formation of the students' volitional qualities in the process of physical education", International Journal of Human Movement and Sports Sciences, Vol.8, No.6, pp. 505-517, 2020. doi: 10.13189/saj.2020.080625

[7] I. Okhrimenko, O. Pasko, L. Prudka, O. Torlo, L. Herman, S. Okhrimenko, R. Perkatyi. "The influence of modern sports technologies on health and professional activity of 
law enforcement officers", Wiadomości Lekarskie, Vol.74, No.6, pp. 1365-1371, 2021. doi: 10.36740/WLek20210611 5

[8] K. Prontenko, G. Griban, I. Bloshchynskyi, I. Melnychuk, D. Popovych, V. Nazaruk, S. Yastremska, D. Dzenzeliuk, I. Novitska. "Improvement of students' morpho-functional development and health in the process of sport-oriented physical education", Wiadomości Lekarskie, Vol.73, No.1, pp. 161-168, 2020. doi: 10.36740/WLek202001131

[9] O. Mozolev, M. Khmara, I. Shorobura, I. Bloshchynskyi, K. Prontenko, O. Polishchuk, L. Zdanevych, K. Krutii. "Comparative analysis of the effectiveness of Polish and Ukrainian basic training programs in physical education for 9-10-year-old pupils", Universal Journal of Educational Research, Vol.7, No.11, pp. 2345-2351, 2019. doi: 10.13189/ujer.2019.071112

[10] G. Griban, K. Prontenko, V. Zhamardiy, P. Tkachenko, M. Kruk, Yu. Kostyuk, Ye. Zhukovskyi. "Professional stages of a physical education teacher as determined using fitness technologies", Journal of Physical Education and Sport, Vol.18, No.2, pp. 565-569, 2018. doi: 10.7752/jpes.2018.02082

[11] V. Zhamardiy, O. Shkola, I. Okhrimenko, O. Strelchenko, A. Aloshyna, F. Opanasiuk, G. Griban, V. Yahodzinskyi, O. Mozolev, K. Prontenko. "Checking of the methodical system efficiency of fitness technologies application in students' physical education", Wiadomości Lekarskie, Vol.73, No.2, pp. 332-341, 2020. doi: 10.36740/WLek202002125

[12] O. Mozolev, I. Bloshchynskyi, O. Alieksieiev, L. Romanyshyna, L. Zdanevych, I. Melnychuk, K. Prontenko, V. Prontenko. "Influence of modern fitness technologies on the state of health and development of motor abilities of 17-19-year-old female students", Journal of Physical Education and Sport, Vol.19, (Supplement issue 3), pp. 917-924, 2019. doi: 10.7752/jpes.2019.s3132

[13] I. T. Mokrova, A. P. Vapaeva, A. Yu. Osipov. "Ispolzovanie sistemyi fitnes-treninga Kangoo Jumps v fizicheskom vospitanii studentok" [Use of Kangoo Jumps fitness system in physical education of female students]. Problemyi sovremennogo pedagogicheskogo obrazovaniya, Vol.59 No.2, pp. 249-253, 2018. Available at: http://research.sfu-kras.ru/publications/publication/352043 06

[14] O. Romanchuk, Yu. Bryskyn, O. Sydorko, M. Ostrovskyi, M. Pitin. Formation of pedagogical college students' readiness for sports and recreation activity, "Journal of Physical Education and Sport", Vol.15, No.4, pp. 815-822, 2015. doi: 10.7752/jpes.2015.04125

[15] O. Kharchenko, N. Kharchenko, I. Shaparenko. "Analysis of the physical development of youth and the state of its health", Wiadomosti Lekarskie, Vol.72, No.4, pp. 575-578, 2019.

[16] Yu. Melnyk. "The influence of educational, physical cultural and healthy work on the formation of the health culture of master's students". Journal of Physical Education and Sport, Vol.19, Suppl. No.1, pp. 219-226, 2019. doi:10.7752/jpes.2019.s1033

[17] G. Griban, O. Kobernyk, N. Terentieva, O. Shkola, Z. Dikhtiarenko, I. Mychka, E. Yeromenko, L. Savchenko, A.
Lytvynenko, K. Prontenko. "Formation of health and fitness competencies of students in the process of physical education", Sport Mont, Vol.18, No.3, pp. 73-78, 2020. doi 10.26773/smj.201008

[18] A. M. Rogowska, I. Pavlova, C. Kuśnierz, D. Ochnik, I. Bodnar, P. Petrytsa. "Does physical activity matter for the mental health of university students during the COVID-19 Pandemic?", J Clin Med, Vol.9, No.11, pp. 3494, 2020. doi:10.3390/jcm9113494

[19] I. R. Bodnar, M. V. Stefanyshyn, Y. V. Petryshyn. "Assessment of senior pupils' physical fitness considering physical condition indicators", Pedagogics, Psychology, Medical-biological Problems of Physical Training and Sports, Vol.20, No.6, pp. 9-17, 2016 doi:10.15561/18189172.2016.0602

[20] M. Imamoglu, O. A. Sener. Comparison of children's motor performances by age and gender, "Universal Journal of Educational Research", Vol.7, No.1, pp. 10-15, 2019. doi: 10.13189/ujer.2019.070102

[21] F. Leuciuc. "Perception on physical education among students", Revista Românească pentru Educaţie Multidimensională, Vol.10, No.2, pp. 134-143, 2018. doi:https://doi.org/10.18662/rrem/51

[22] O. Azhyppo, V. Pavlenko, V. Mulyk, K. Mulyk, L. Karpets, T. Grynova, M. Sannikova. "Direction of teaching the subject of physical education by taking into account opportunities of institution of higher education and interests of student youth", Journal of Physical Education and Sport, Vol.18, No.1, pp. 222-229, 2018. doi:10.7752/jpes.2018.01029

[23] S. Prysiazhniuk, V. Tolubko, D. Oleniev, Yu. Parczevskyy, K. Prontenko, G. Griban, O. Zhyrnov. "The influence of physical activities on biological age parameters of the first-year female students from the special medical department", Journal of Physical Education and Sport, Vol.18, No.2, pp. 561-564, 2018. doi:10.7752/jpes.2018.02 081

[24] O. Zavydivska, N. Zavydivska, O. Khanikiants. "Self-management as a condition for creating a health culture among students", Journal of Physical Education and Sport, Vol.16, No.1, pp. 592-597, 2016. doi:10.7752/jpes.2016.s1093

[25] B. Zelenskyi, R. Zelenskyi. "Motivation: attitude of students of higher education institutions of the I-II accreditation levels toward physical education classes", Theory and Methods of Physical Education, Vol.18, No.3, pp. 114-125, 2018. doi:10.17309/tmfv.2018.3.02

[26] M. Mohsin. "Adaptation perspective in implementing physical education in schools", International Journal of Sports and Physical Education, Vol.4, No.2, pp. 28-36, 2018. doi:http://dx.doi.org/10.20431/2454-6380.0402004 www.arcjournals.org

[27] A. Bolotin, V. Bakayev. "Structure and content of the educational technology of managing students' healthy lifestyle". Journal of Physical Education and Sport, Vol.15, No.3, pp. 362-364, 2015. doi:10.7752/jpes.2015.03054

[28] P. Montesano, F. Mazzeo. "Sports activities in obese teenagers improve social inclusion and health", Sport Mont, Vol.17, No.1, pp. 55-60, 2019. doi: 10.26773/smj.190210 
[29] A. E. Carter. "The Miracles of Rebound Exercise", The National institute of Reboundology and Health, Inc. Edmonds, Washington, 1979. 188 p.

[30] J. Vance, J. A. Mercer. "Impact Forces During Running in a Novel Spring Boot", Department of Kinesiology, University of Nevada, Las Vegas. 1999. Available at: https://jump-dich-fit.de/fileadmin/user_upload/Vorteile/Stu dien/University\%20of\%20Nevada\%20Study.pdf

[31] T. G. Batilani, I. C. Belem, J. Both. "Different profiles in terms of motivation and concerns of physical education students", Movimento, Vol.24, No.2, pp. 619-632, 2018. doi:10.22456/1982-8918.74947

[32] A. I. Cucui. "Study on sports activities in the free time of gymnasium cycle students", Revista Românească pentru Educaţie Multidimensională, Vol.10, No.4, pp. 82-91, 2018. doi:https://doi.org/10.18662/rrem/74

[33] A. Stachon, J. Pietraszewska, A. Burdukiewicz, J. Andrzejewska. "The differences in fat accumulation and distribution in female students according to their level of activity", Human Movement, Vol.17, No.2, pp. 87-93, 2016. doi:10.1515/humo-2016-0009

[34] S. Prysiazhniuk, V. Tolubko, D. Oleniev, Yu. Parczevskyy, K. Prontenko, G. Griban, O. Zhyrnov. "The influence of physical activities on biological age parameters of the first-year female students from the special medical department", Journal of Physical Education and Sport, Vol.18, No.2, pp. 561-564, 2018. doi:10.7752/jpes.2018.02 081

[35] World Health Organization. "Global recommendations on physical activity for health". Available at: http://www.who.int/dietphysicalactivity/factsheet_recomm endations.

[36] G. Griban, N. Lyakhova, O. Tymoshenko, Zh. Domina, N. Dovgan, M. Kruk, I. Mychka, P. Tkachenko, B. Semeniv, G. Grokhova, N. Zelenenko, K. Prontenko. "Current state of students' health and its improvement in the process of physical education", Wiadomości Lekarskie, Vol.73, No.7, pp. 1438-1447, 2020. doi: 10.36740/WLek202007124

[37] I. Bloshchynskyi, G. Griban, I. Okhrimenko, V. Stasiuk, D. Suprun, O. Nedvyha, et al. "Formation of psychophysical readiness of cadets for future professional activity", The Open Sports Sciences Journal, Vol.14, pp. 1-8, 2021. doi: 10.2174/1875399X02114010001

[38] G. Griban, O. Tymoshenko, V. Arefiev, L. Sushchenko, Zh. Domina, T. Malechko, I. Zhuravlov, P. Tkachenko, A.
Baldetskiy, K. Prontenko. "The role of physical education in improving the health status of students of special medical groups". Wiadomości Lekarskie, Vol.73, No.3, pp. 534-540, 2020. doi: 10.36740/WLek202003125

[39] K. Prontenko, G. Griban, A. Aloshyna, S. Bezpalyi, T. Yavorska, S. Hryshchuk, P. Tkachenko, D. Dzenzeliuk, I. Bloshchynskyi. "The physical development and functional state as the important components of the students' health", Wiadomości Lekarskie, Vol.72 No.12, part 1, pp. 2348-2353, 2019. doi: 10.36740/WLek201912115

[40] G. Griban, K. Prontenko, V. Zhamardiy, P. Tkachenko, M. Kruk, Yu. Kostyuk, Ye. Zhukovskyi. "Professional stages of a physical education teacher as determined using fitness technologies", Journal of Physical Education and Sport, Vol.18, No.2, pp. 565-569, 2018. doi: 10.7752/jpes.2018.02082

[41] D. Kyslenko, K. Prontenko, V. Bondarenko, Yu. Iukhno, R. Radzievskii, V. Prontenko, O. Kizyun. "Development of the physical qualities of future specialists in protective activities due to the use of the kettlebell sport during studies", Journal of Physical Education and Sport, Vol.17, No.2, 789-794, 2017. doi:10.7752/jpes.2018.s2159

[42] G. Griban, N. Lyakhova, O. Tymoshenko, Zh. Domina, N. Dovgan, M. Kruk, I. Mychka, P. Tkachenko, B. Semeniv, G. Grokhova, N. Zelenenko, K. Prontenko. "Current state of students' health and its improvement in the process of physical education", Wiadomości Lekarskie, Vol.73, No.7, pp. 1438-1447, 2020. doi: 10.36740/WLek202007124

[43] K. Prontenko, G. Griban, V. Prontenko, F. Opanasiuk, P. Tkachenko, Ye. Zhukovskyi, Yu. Kostyuk. "Health improvement of cadets from higher military educational institutions during kettlebell lifting activities", Journal of Physical Education and Sport, Vol.18, No.1, pp. 298-303, 2018. doi:10.7752/jpes.2018.01040

[44] N. Dinc, P. Guzel, S. Ozbey, T. Besikci, S. Seyhan, N. Kalkan, G. Gezer. "Obesity prevalence and physical fitness in school-aged children", Universal Journal of Educational Research, Vol.7, No.3, pp. 659-663, 2019. doi: 10.13189/ujer.2019.070303

[45] G. Griban, O. Tymoshenko, V. Arefiev, L. Sushchenko, Zh. Domina, T. Malechko, I. Zhuravlov, P. Tkachenko, A. Baldetskiy, K. Prontenko. "The role of physical education in improving the health status of students of special medical groups", Wiadomości Lekarskie, Vol.73, No.3, pp. 534-540, 2020. doi: 10.36740/WLek202003125 